\title{
Skeleton of the Fossil Shark Isurus denticulatus from the Turonian (Late Cretaceous) of Germany-Ecological Coevolution with Prey of Mackerel Sharks
}

\author{
Cajus G. Diedrich \\ Private Research Institute Paleologic, Petra Bezruce 96, CZ-26751 Zdice, Czech Republic \\ Correspondence should be addressed to Cajus G. Diedrich; cdiedri@gmx.net
}

Received 19 May 2013; Accepted 24 July 2013; Published 13 May 2014

Academic Editors: A. Garcia-Alix, A. M. F. Valli, and F. Vega

Copyright (C) 2014 Cajus G. Diedrich. This is an open access article distributed under the Creative Commons Attribution License, which permits unrestricted use, distribution, and reproduction in any medium, provided the original work is properly cited.

An Isurus denticulatus (Glickman, 1957) shark skeleton from the late Turonian (Late Cretaceous) of Germany is described within a diverse upwelling influenced fish fauna of northern Germany, Europe. It was found in the turbiditic marly limestones at the submarine Northwestphalian Lippe Swell in the southern Proto-North Sea Basin. Compared to modern mackerel shark Isurus oxyrinchus Rafinesque, 1809, including cranial denticles, this allows a revision of the younger synonym "Cretoxyrhina Glickman, 1964". Within the Cretaceous Isurus, a loss of the lateral tooth cusps and nutritive clefts of the roots (considered as plesiomorphic character of the Lamnidae) took place from the Albian (Early Cretaceous) to the Campanian (Late Cretaceous). The tooth morphology changed during the Albian-Turonian from a tearing (I. denticulatus) to a cutting (I. mantelli) type (ConiacianCampanian). The complete lateral cusplet and symphyseal teeth reduction in Isurus at the end of the Cretaceous seem to be a result of the coevolutionary changing feeding habits of a worldwide expanding shark. In a second evolutionary adaptation, parallel to the new radiation of marine mammals (Paleocene/early Eocene), from Isurus, the white shark ancestors (Carcharodon) seem to originate. In another radiation from Isurus, coevolving with appearance of dolphins and further marine mammal evolution within the Middle Miocene, a second time Isurus developed serrated teeth (I. escheri).

\section{Introduction}

Macroneoselachians have in most cases ancestors reaching into the upper early or lower Late Cretaceous (e.g., [16]). The largest shark of the lower-middle Late Cretaceous (Cenomanian-Campanian) was described as Isurus $[7,8]$ or Cretoxyrhina [9] controversially until today (e.g., [6]), which was globally distributed (Figure 1(a)). Cretaceous and Tertiary shark researchers did not review the isurid sharks in the past critically, whereas complete skeletons are rare form different stratigraphical units (e.g., $[6,10])$. The revision of Mesozoic Isurus and its evolutionary trend, especially in the dental morphology change, is highly important to understand its fairly long evolutionary trend, which is the basic to understand the white shark evolution and non-origin of megatooth sharks from isurid ancestors (cf. [3]). Whereas the dentition changed already strongly in the Cretaceous (e.g., (cf. [11-15]), and herein continuing in the Tertiary), it can be demonstrated, that the squamation and vertebrae retained with plesiomorph characters. Those are found similar at modern Isurus (cf. [5]), and Cretaceous "Cretoxyrhina" of North-America (cf. [1]), and the herein described new skeleton of Germany. The squamation, which is strongly different in the Lamna/Isurus shark groups (cf. [5]) is especially important for the revision of "Cretoxyrhina." For this revision herein, as well-stratified, collected, isolated material from lower Cenomanian to late Turonian layers in northwestern Germany, Münster Cretaceous Basin of the Proto-North Sea Basin of Europe is used (Figure 1(b)). A new late Turonian Isurus skeleton and new Isurus teeth from the middle Eocene of northern Germany (cf. [16]) are further important. Those and a review of the literature allow to present a new view of the evolutionary trend of this genus from the Cretaceous to Neogene. There seems to be not an "extinction" within the Maastrichtian (fossil record gap only, and climatic reason combination), instead herein it will be discussed to be a fluent 


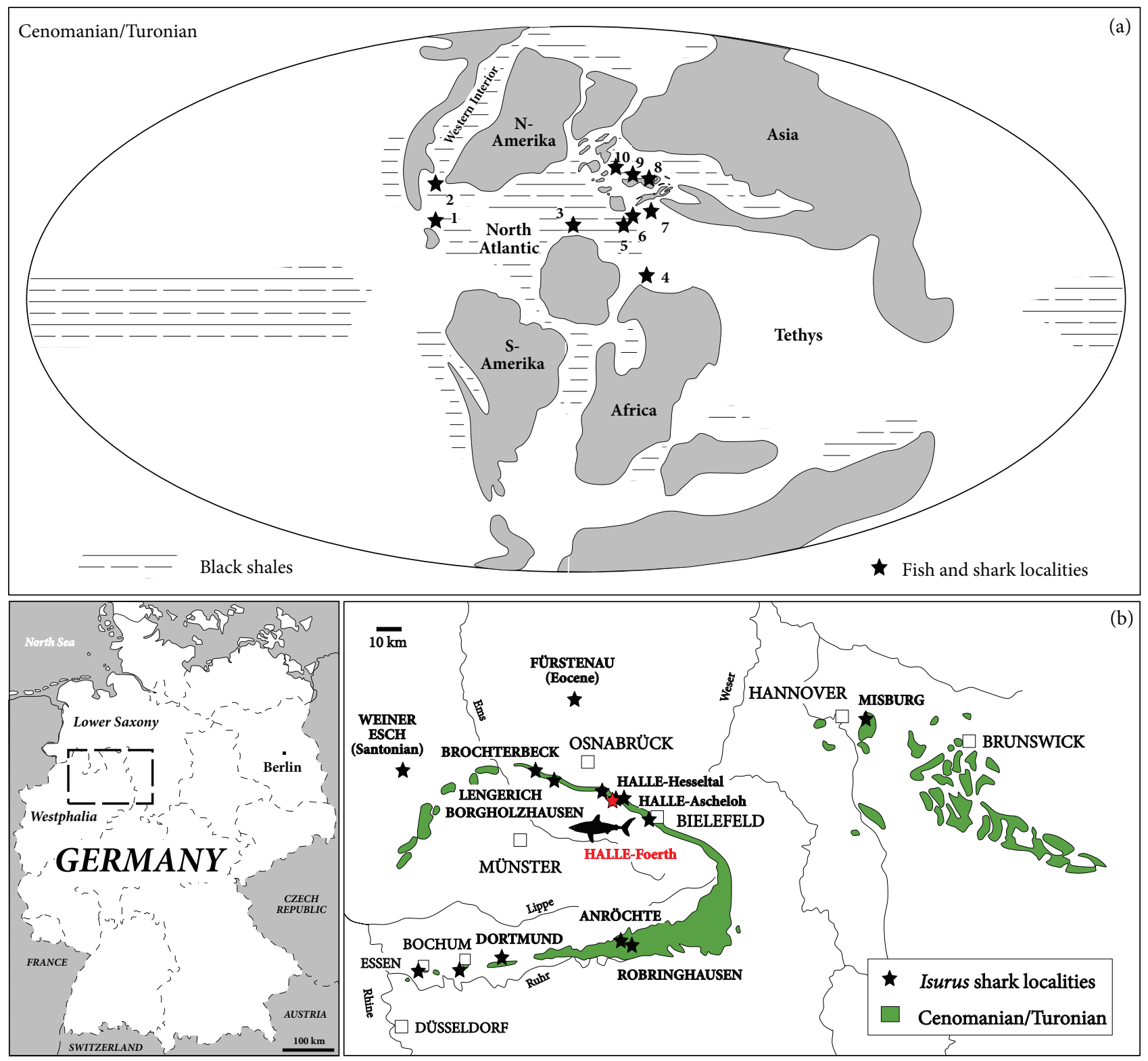

Figure 1: (a) Late Cretaceous fish localities with Isurus remains 1-2. USA, 3. Maroc, 4. Lebanon, 5-6. Italy (Comen, Sicily), 7. Croatia, 8. Czech Republic, 9. Germany, 10. England. (b) Location of the shark skeleton site in the Halle-Foerth quarry and other Cretaceous Isurus sites of northwestern Germany.

transition into the Tertiary to Modern Isurus. This is seen most recent even to the "ancestor" of the modern white sharks, which started in the Palaeocene, which is seen most recent even to be the "ancestor" of the modern Carcharodon. These white sharks started in the Palaeocene, nearly parallel in evolution with the megatooth sharks. This is latter developed instead from Lamna (cf. [3]). The repeating tooth morphology changes of Isurus and radiation from the Cretaceous to Neogene as coevolutionary adaptation onto its marine large prey will be discussed herein, explaining finally "general repeating morphology change trends" in the jaw and tooth form within lamnid sharks. It was similarly discussed for the Tertiary white/megatooth shark evolution and prey adaptation onto marine mammals such as whales, sirenians, and seals (cf. [3]). Here, all skeletal remains including teeth, vertebrae, cartilage, and dermal denticles of recent fossil isurid skeletons as well as isolated remains are compared.

\section{Sedimentary Geology and Stratigraphy}

The outcrop where the skeleton was found exposes sediments ranging from the late Cenomanian, the Turonian, and to the early Coniacian $[22,23]$. The overturned late Cretaceous carbonates strain WNW-ESE and dip NE at $32^{\circ}$. The skeleton was found in the Weissgraue Kalkstein Member of the late Turonian (Figure 2). The carbonates consist of 


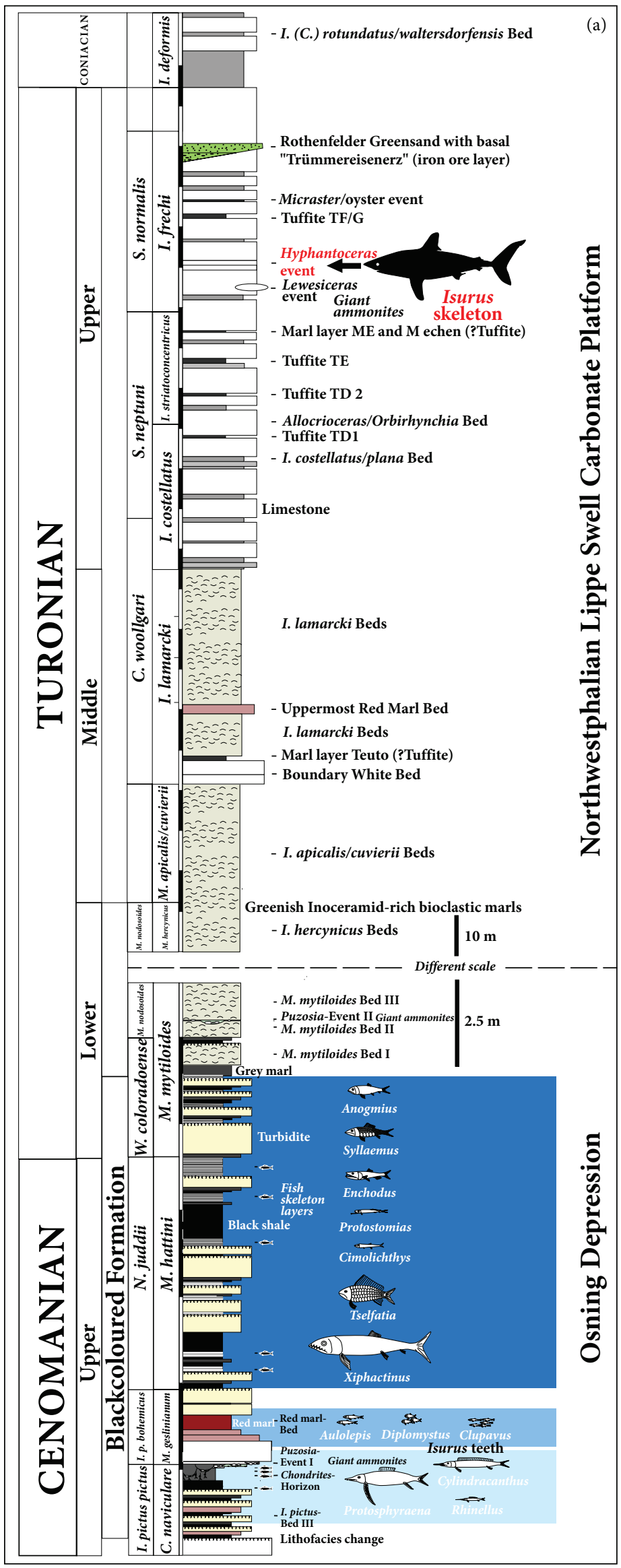

FIGURE 2: Continued. 


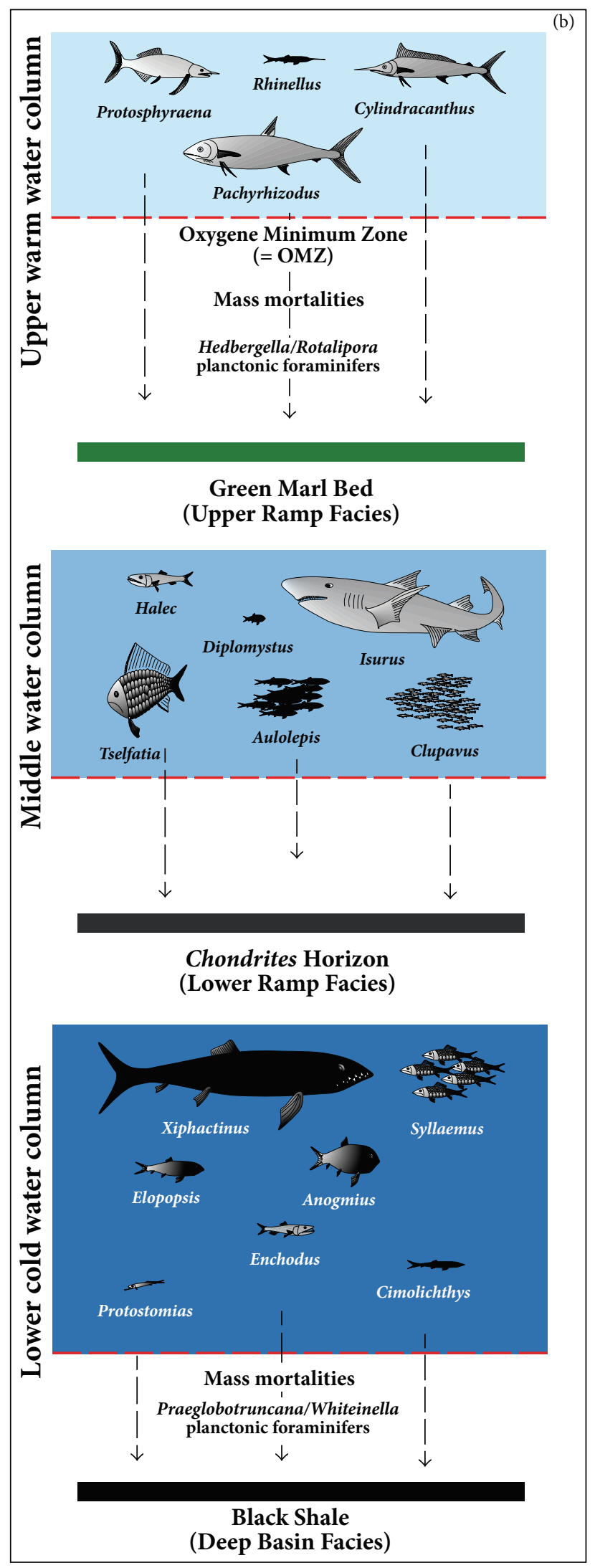

Figure 2: (a) Stratigraphy of the Halle quarry sections (combined quarries Hesseltal and Foerth), with the position of fish-rich beds, isolated Isurus tooth, and skeletons. (b) Mortality models due to the decreasing of the oxygen minimum zone within the water column during algae blooming and mass-foraminifera/fish-mortalities as result of upwelling events (from [17]). 
alternating layers of $5-20 \mathrm{~cm}$ thick-bedded homogenous, grey, wavy limestone ( $90 \%$ carbonate) and thin, dark marl layers (50-60\% carbonate). A referencial layer called the Hyphantoceras event is situated $14.4 \mathrm{~m}$ above the horizon of a markant marl layer (= ME) event in the ammonite biozone of Suprionocyclus normalis and the inoceramid biozone of Inoceramus frechi (Figure 2). The Turonian matrix which yielded the skeleton was thin sectioned for microfacies and environmental analysis. The results were compared to the known marine Cenomanian/Turonian palaeoenvironments ([22-24], Figure 2). Typical of the Hyphantoceas event, the layers are rich in ammonites and other marine taxa. They are decimeter thick, white foraminifera wackestones, and foraminfera mudstone layers. This turbiditic microfacies is typical of the lower slope [23, 24], which was deposited at the margin of a carbonate platform, the Northwestphalian Lippe Swell, below the storm wave base $(>30 \mathrm{~m})$. A slight bioturbation of Chondrites, in the thin grey marls, indicates periodic dysoxic conditions on the bottom floor (cf. $[23,25])$.

\section{Material and Methods and Their Biostratigraphy}

An incomplete neoselachian skeleton of Isurus was firstly discovered in northwest Germany in the summer of 1989 by $M$. Plesker. It is now housed in the Museum Natur und Mensch Bielefeld (north Germany). The locality is the Foerth quarry, west of Halle/Westphalia (coordinates R 3455.20 and $H$ 5771.30, topographical map 1:25000, sheet 3916 Halle/Westphalia). Parts of the skeleton were first visible only in cross section in the quarry wall. At the time, the cranial part was already destroyed by quarry activities. In two days, more than 60 slabs were excavated. The material was prepared mechanically by S. Schubert over two years.

It was fortunate to find unprepared slabs in which cartilage fragments are present, especially the anterior ones, where skull cartilage fragments were found. Because of the in removal of the marls between the vertebrae during the mechanical preparation, it was not possible to take samples of different body regions. The only parts sampled were three large blocks from the cranial region. Dark grey marl of the slab surface was scratched off mechanically for chemical processing with $99 \%$ dilute acetic acid. In the next step, the sediment was washed using a $0.063 \mathrm{~mm}$ sieve. The residues consisted of hundreds of dermal denticles, a few small teeth, cartilage fragments, crinoid remains, and agglutinating foraminifers. The microfossils were hydrated for two days and dried in a stove at $50^{\circ}$ Celsius. Under microscope, hundreds of 0.4-2.2 mm small placoid denticles as well as small cartilage fragments were isolated.

In addition to this Turonian skeleton, newly collected isolated teeth and dermal denticles from other German sites such as Halle-Ascheloh (early Cenomanian), HalleHesseltal (late Cenomanian), and Ochtrup (late Santonian) are important in the understanding of the systematics of the genera Cretoxyrhina and Isurus.

Isolated teeth and denticles from the Halle/Ascheloh locality (NW Germany, Figure 1) are additionally described here in the analyses. These were sieved from slump sediments in the M. dixoni biozone of the early Cenomanian. However, in this slump, the complete marine fauna was condensed from different biozones of the lower Cenomanian. This is indicated by the ammonite Mantelliceras dixoni and the belemnite Neohibolites ultimus, and phacoid structures, such as noncemented "inoceramid prisma sand" [4].

Other teeth and dermal denticles from the HalleHesseltal site (NW Germany, Figure 1) are from the Metoicoceras geslinianum biozone (Chondrites Horizon and Puzosia event I). This indicates a late Cenomanian age, well dated by the ammonids, inoceramids, and high resolution multistratigraphy [23] (Figure 2). From this black-coloured formation (Cenomanian/Turonian boundary) of the Teutoburger Wald and northern Germany in general, a fish-rich fauna is known [17], which is important to understand the possible prey and taphonomy of fish skeletons in the Proto-North Sea Basin of Europe (Figure 3).

Isolated tooth material of the vertebrate-rich late Santonian locality Werner Esch near Ochtrup (NW Germany, Figure 1) is from conglomerates which intercalate into limestone arenites. Those series are dated by the inoceramids Sphenoceramus patootensis and the belemnites Gonioteuthis granulata and Actinocamax verus [26].

Finally, new and abundant Isurus teeth, which were found recently in the middle Eocene Fürstenau Formation (Lutetian) of north-western Germany [16], were included in the analyses.

Cartilage fragments of a Coniacian I. mantelli from the Niobrara Fm from Kansas, were chemically prepared in a 99\% diluted acetic acid solution.

\section{Palaeontology}

4.1. Megafauna of the Shark Skeleton Bed. Rhynchonellids, crinoids, and heteromorph ammonites such as Hyphantoceras reussianum, Eubostrychoceras saxonicum, and Scaphites geinitzii are associated with the shark remains. The diverse ammonite fauna of the Hyphantoceras event described for the Halle/Foerth locality (cf. [22]) indicates normal saline, marine boreal conditions of the middle deep shelf.

Two small selachian teeth cusp fragments from Hexanchus microdon, one tooth from Scyliorhinus cf. elongatus and teeth of the teleostean Enchodus sp. were found in the sieved samples associated with the shark skeleton. Twelve teeth cusps from a Scymnorhinidae are other small scavenger shark remains.

4.2. Taphonomy of the Skeleton. The skeleton was found oriented E-W in the quarry, with the caudal part directed to the west. Many vertebrae, a few isolated teeth, dermal denticles, and cartilage from the "head region" (around skull/jaw cartilage) are mainly preserved. Parts of the vertebral column are nearly articulated (Figure 4(a)). In the medial region, five fragments consisting of four to six articulated vertebrae are preserved. Disarticulated vertebrae are few scattered. The caudal column does not show any articulation. Most of the vertebrae are embedded on their flat centre side in the current stable position. Five teeth are found posteriorly between 


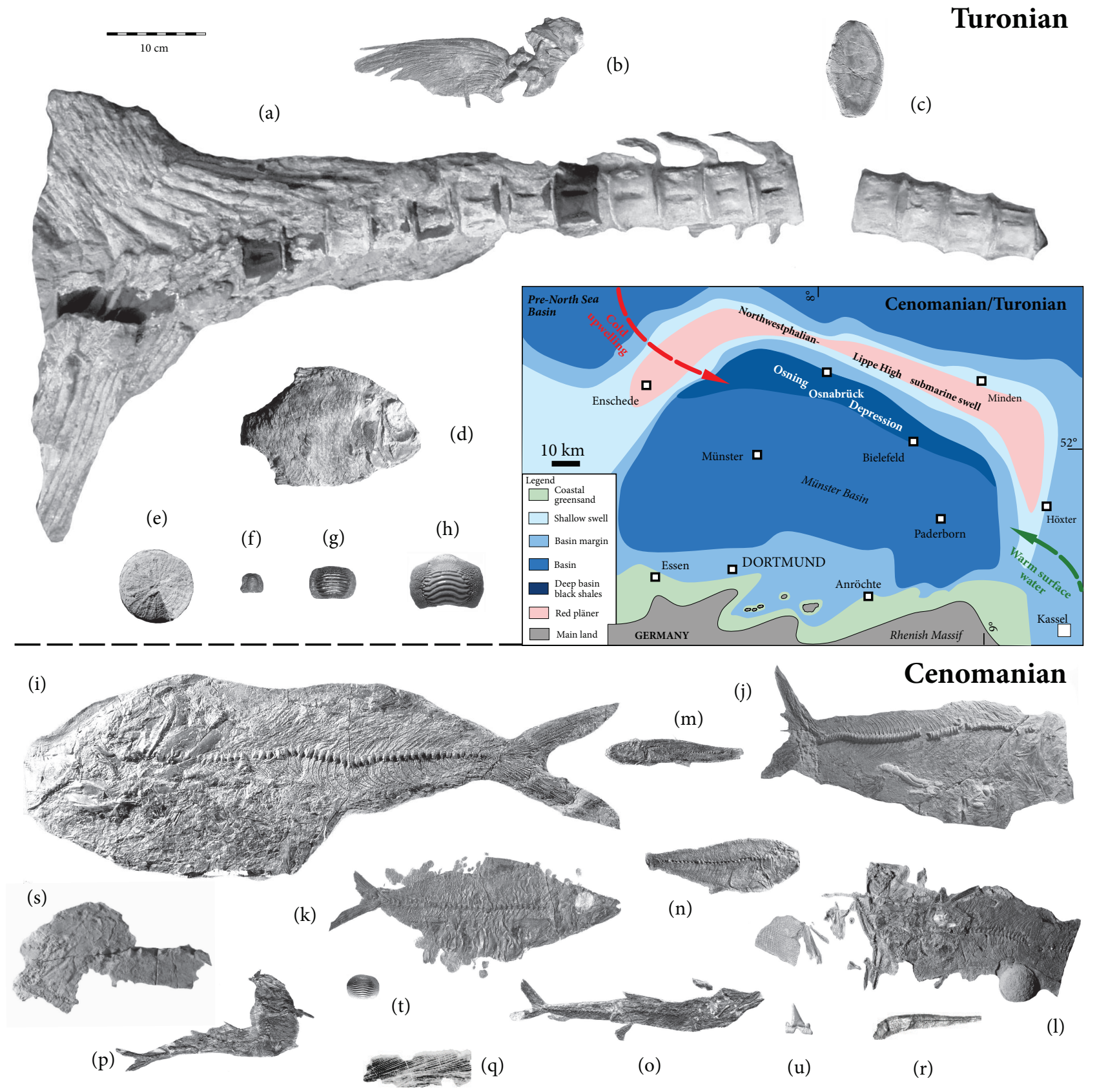

FIGURE 3: Fish and shark biodiversity selection of the Cenomanian/Turonian boundary to late Turonian of the Münster Cretaceous Basin of northwest Germany (composed from [17]) (a) Xiphactinus caudal fin and vertebral column, (b) Xiphactinus pectoral fin, (c) Xiphactinus scale, (d) Berycopsis skeleton, (e) Isurus vertebra, (f) Ptychodus tooth, (g) Ptychodus tooth, (h) Ptychodus tooth, (i) Pachyrhizodus skeleton, (j) Anogmius skeleton, (k) Syllaemus skeleton, (l) Elopopsis skeleton, (m) Clupavus skeleton, (n) Diplomystus skeleton, (o) Cimolichthys skeleton, (p) Aulolepis skeleton, (q) Protosphyraena pectoral fin, (r) Cylindracanthus rostrum, (s) Paraorthacodus skeleton (see details in [17]).

the vertebrae, and many placoid denticles and cartilage fragments are also preserved.

On a first glance, the taphonomical context suggests a complete caudal disarticulation, with the small vertebrae being scattered. In a second step, the central column fell apart into articulated pieces. Only the cranial (skull or jaw, unclear) cartilage is preserved, but in smaller fragments only. The few teeth were displaced early from the jaws and caught (not appropriated) between the vertebrae. The cranium and first vertebrae were destroyed by the quarry activities.

The preservation of the skeleton seems to be linked with the paleoenvironment: the sediments of the Hyphantoceras event are typical of the lower slope, which allows the articulation of large carcasses. Turbidites within the slope facies preserved disarticulated shark remains but rarely complete skeletons. The best preservation cases are found in the 


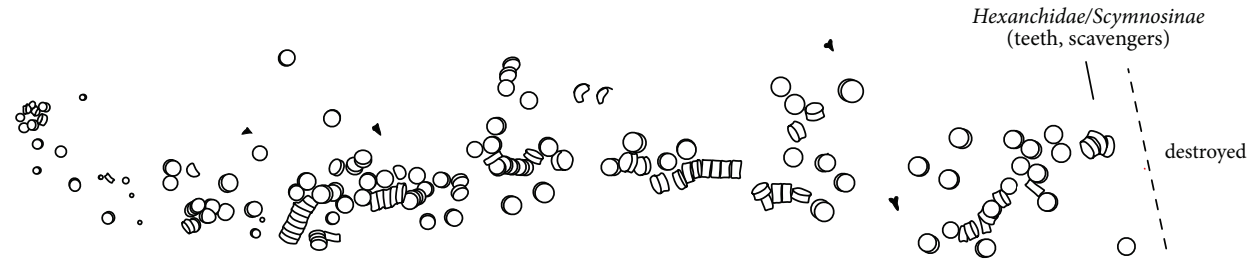

(a)

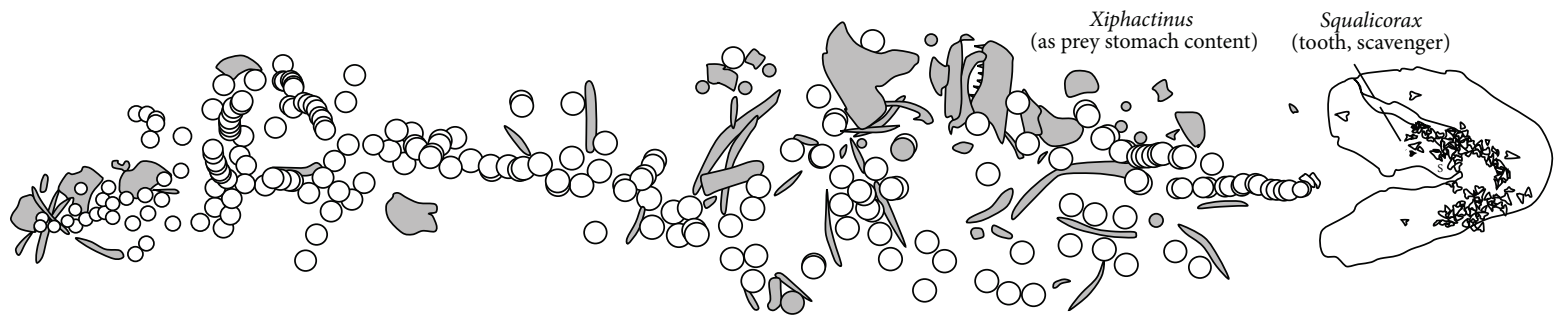

(b)

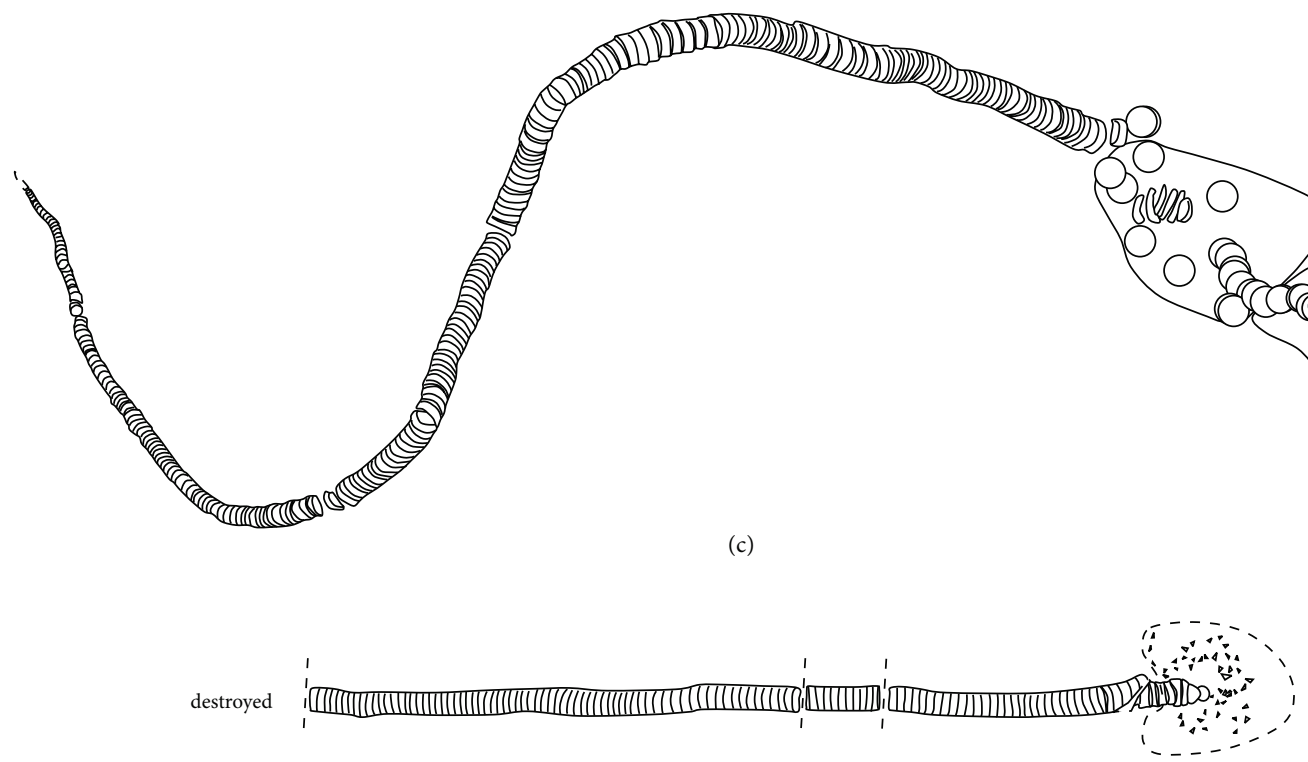

(d)

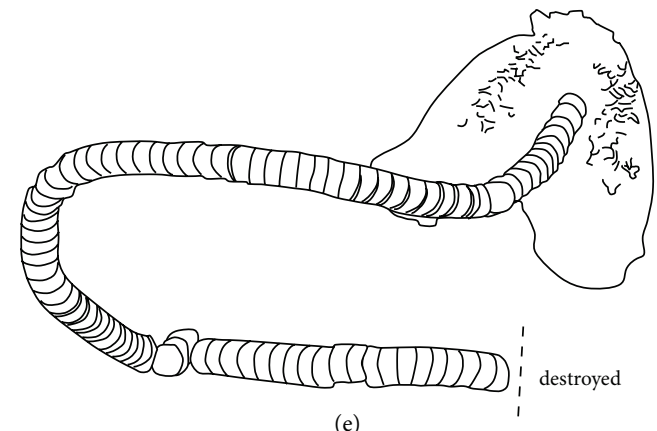

$100 \mathrm{~cm}$

(e)

Figure 4: Interpretative drawings of Late Cretaceous Isurus-skeletons. (a) Partly disarticulated skeleton without skull from the late Turonian of Germany (NMB no. 3916 Foerth-Isurus-1); (b) partly disarticulated but nearly complete skeleton from the Niobrara Formation (Coniancian to Campanian) of USA with its last prey, a huge teleostean Xiphactinus audax (in black, redrawn after [18]; KUVP no. 247 after [19]); (c) articulated skeleton from the Niobrara Formation (Coniancian to Campanian) of USA (redrawn after [13]; FHSM no. VP-2187); (d) partly preserved articulated skeleton from the "Senonian" (Coniacian/Santonian) of Italy (redrawn after [20]); (e) partly preserved articulated skeleton from the Niobrara Formation (Coniancian to Campanian) of USA (redrawn after photos of Everhart, STERN no. 01). 
black shale of the ramp facies in the Osning-Depression, at the Cenomanian/Turonian boundary, or during the socalled anoxic event II at the Teutoburger Wald, where many articulated fish are found [17, 27].

All recently known skeletons of Cretaceous isurids are compared here in their taphonomy (Figure 4). The historically first Late Cretaceous isurid skeleton (Figure 4(d)) was described [20] from the northern Italian "Senonian." An incomplete vertebral column, consisting of about 100 vertebrae, is preserved in three pieces, with the caudal one being lost. The total length of this incomplete skeleton measures $285 \mathrm{~cm}$. The straight column orientation, without any disarticulated vertebrae, looks like a roll of coins. The figures show a few teeth and vertebrae only. The skull (cartilage) is preserved.

The skeleton of "Cretoxyrhina mantelli" from the Niobrara Formation (Coniacian to Campanian) of North America was described [28] with isolated teeth, Meckel's cartilage, dermal denticles, and isolated vertebrae, without taphonomic map of the specimen. Three skeletons from the Niobrara Formation (Coniacian to Campanian) of North America were described as "Cretoxyrhina mantelli Agassiz" [6, 10-15, 28, 29]. They represent the world's best preserved skeletons. The first finding (Figure 4(e), (cf. [29])) is strongly U-curved, the most distal caudal column being lost. The skull is preserved with cartilage and hundreds of teeth in nearly anatomical position. Interestingly, the stomach contents are preserved; they consist of fragments of a five-meter long giant bony fish Xiphactinus audax (Figure 3(b), after [18]). Another roughly five-meter long skeleton (Figure 3(c), FHSM VP-2187, after [18]) is the most complete skeleton ever known. Its vertebrae and teeth are well described but not the denticles (cf. [18]). Dermal denticles were mentioned at least [13] but not figured. However, the descriptions fit to the main types figured herein from several sites and specimens. The S-shaped vertebral column of this seven meter long skeleton is mostly completely articulated with only the stomach region vertebrae slightly disarticulated. The jaws are preserved with all their teeth, which allows a reconstruction of the dentition (cf. $[12,28])$.

\subsection{Systematics}

Class Chondrichthyes Huxley, 1880.

Subclass Euselachii Bonaparte, 1838.

Cohort Euselachii Hay, 1902.

Subcohort Neoselachii Compagno, 1977.

Supraorder Galeomorphii Compagno, 1973.

Order Lamniformes Berg, 1958.

Family Lamnidae Müller and Henle, 1838.

Genus Isurus Rafinesque, 1810.

Isurus denticulatus Glickman, 1957.

Figures 3-7.

General Description. The incomplete, but first skeleton of its species, was found in the late Turonian of Halle/Westphalia
(Foerth Quarry). This skeleton consists of 149 partially articulated vertebrae, five teeth (one anterior, one lateral, and three rootless crowns of lateral teeth), Meckel's cartilage fragments of the cranial region, and about 100 cranial dermal denticles. This specimen is housed in the NMB as no. 3916 Foerth-Isurus-1.

Vertebrae. One hundred forty-nine vertebrae are present (Figure 5(a)). Two of them are not prepared and not visible in the figures. Two of the 147 figured vertebra, vertebra 72 and vertebra 126, were sectioned: they show the typical neoselachian and lamnid asterospondylic structure (Figures 5(b) 1 and 5(b) 2). The largest cranial vertebra is $6 \mathrm{~cm}$ in diameter with a width of $26 \mathrm{~mm}$; the smallest caudal vertebra measures $26 \mathrm{~mm}$ in diameter and $5 \mathrm{~mm}$ wide. The haemapophysic and neurapophysic grooves are in the cranial and middle vertebral column. They are rectangular in horizontal cross section (vertebra 72), changing to oval and round in outline in the caudal region (vertebra 148, Figure 5(a)). The diameter increases from the cranial to the vertebra 72 (Figure $5(\mathrm{a})$ ), starting at $13 \times 4 \mathrm{~mm}$ and getting smaller towards vertebra 126 at $6 \times 4 \mathrm{~mm}$ caudal. The neural and haemal arch grooves radiate from the centre of the vertebra (Figure 5(b)). Concentric growth lines are visible in cross sections (Figure 5(b)). Both sectioned vertebrae are composed of radiating lamellae (white coloured, Figure 5(b)) bifurcating in their outer part. In between these lamellae, carbonate sediment is present. The lamellae are visible in the outer lateral, dorsal, and ventral views (Figure 5(b)). They are preserved in between the anterior and posterior vertebral surface. Their number decreases from the cranial to the caudal region (Figure 5(a)-5(b)). Fourty, partly fused connected lateral become are reduced in diamater $(18 \mathrm{~mm})$ at vertebra 126 . The most caudal preserved vertebra has no lamella but has a perforated surface structure.

Dermal Denticles. A few cranial dermal denticles of shagreen type are present. Three clear, but possibly four, morphological types are recognized in the area of the gills or of the mouth, as well as in the posterior cranial area.

(i) The first large type I (5 to $15 \mathrm{~mm}$ in length) is dropshaped in outline (Figures 5(d) 1-5 and 7(n)-7(r)). The enameloid cusp stands straight to slightly angled on the basal plate. The morphology varies from high to low drop-shaped, while the surface is covered with 5 to 11 ridges starting with the basal and reaching the mid-high of the cusp. Basal plates are ventrally rhomboid-shaped with central foramina (Figures 5(d) 5 and $7(n)-7(r))$. In lateral or dorsal views, they have an inverted anchor shape.

(ii) The second type II (Figures 5, 6, and $7(\mathrm{~s})-7(\mathrm{v})$ ) is less than $5 \mathrm{~mm}$ long and is clearly separated into the enameloid cusp and the basal plate. Three to six longitudinal ridges ornament the rhomboidal cusps. These ridges completely cover the enamel. The midto-high basal plate has a central foramina.

(iii) A third type III may be present, corresponding to 1$2 \%$ of the dermal denticle material only (Figure $5(\mathrm{~d}$ ) 11-12). It is irregular in outline and without any 
(a)
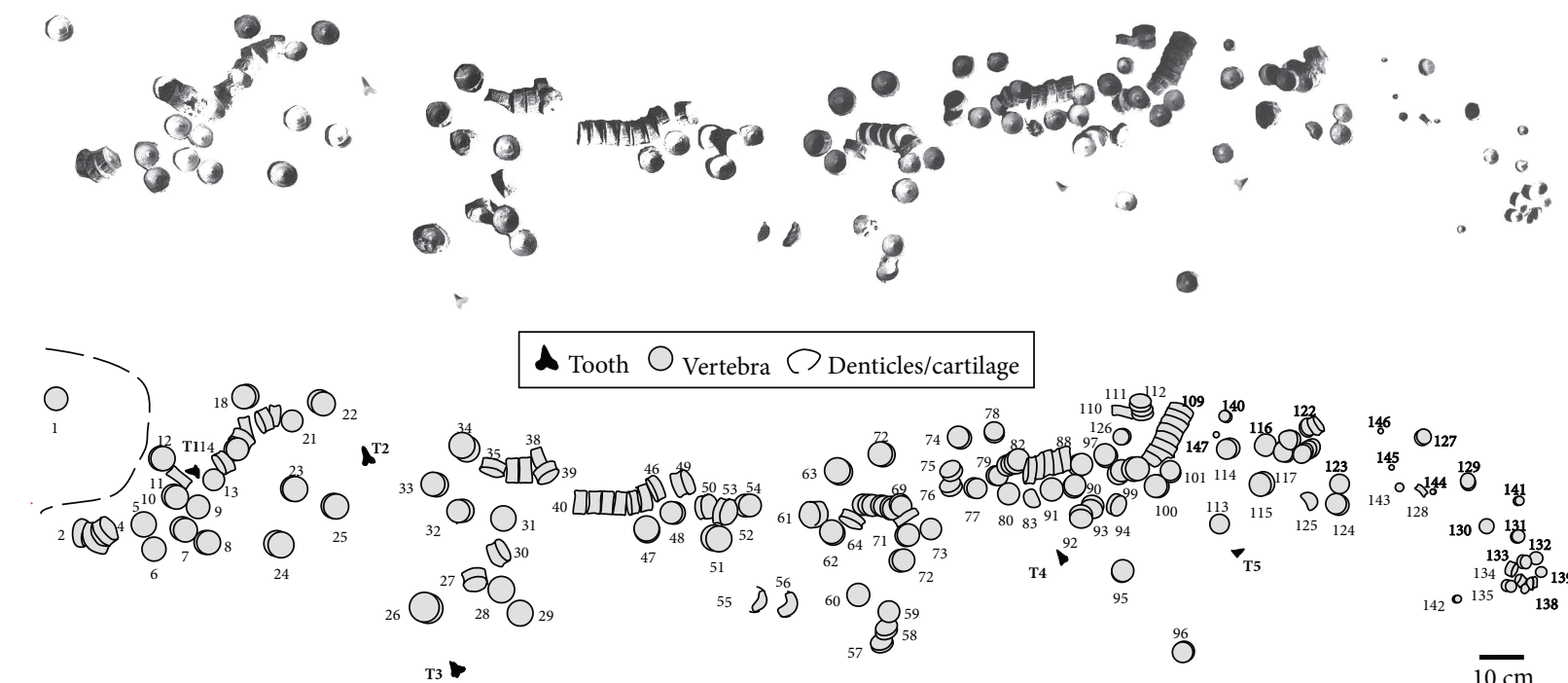

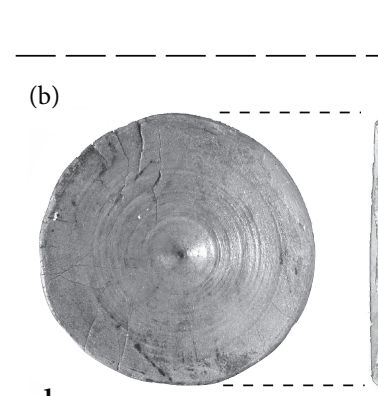

1
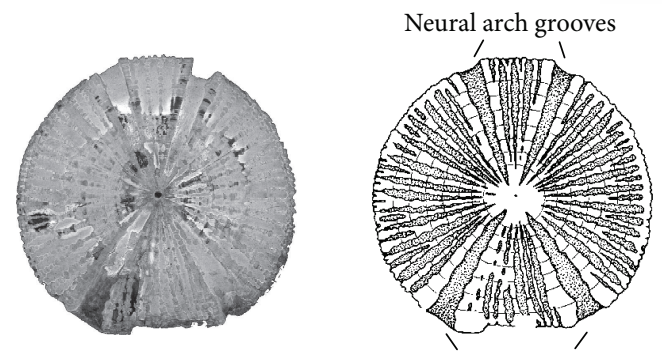

Haemal arch grooves
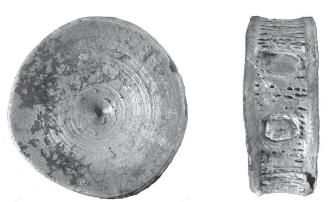

2

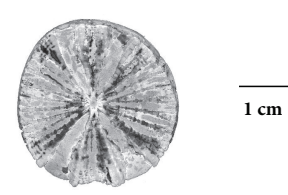

Neural arch grooves

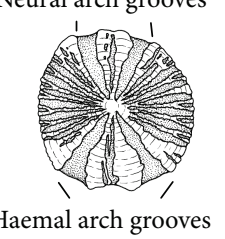

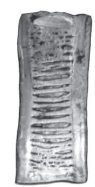
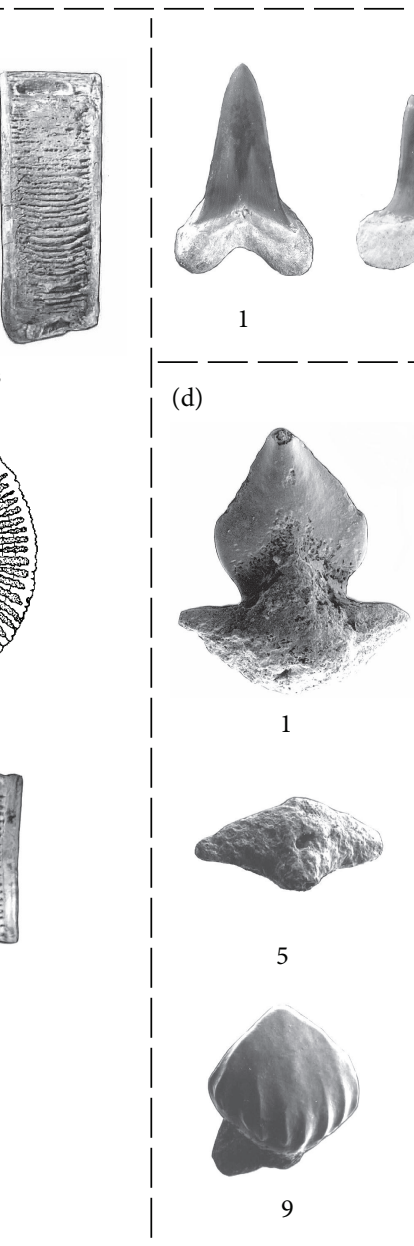
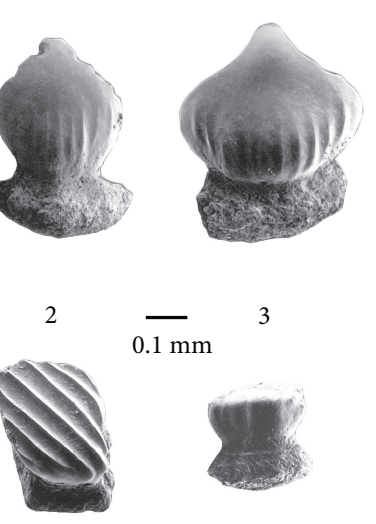

$\overline{0.1 \mathrm{~mm}}$
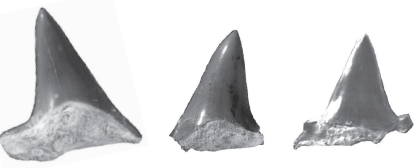

2
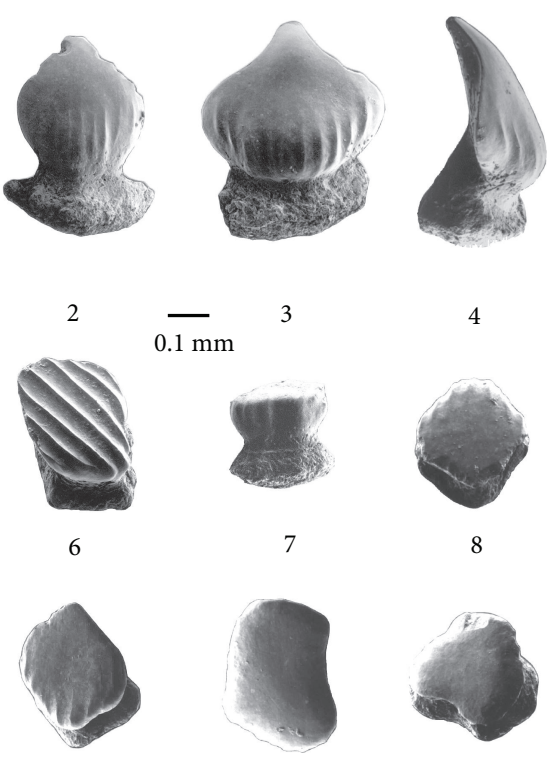

10

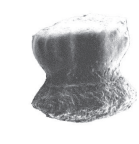

7

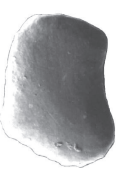

11

Figure 5: Skeleton of Isurus denticulatus (Glickman, 1957) (NMB no. 3916 Foerth-Isurus-1) from the late Turonian (Suprionocyclus normalis Zone) of Halle/Westphalia (Germany). (a) Photo without vertebra 71, 147, and teeth and interpretative drawing of the skeleton with integrated vertebra 71, 147, and teeth. (b) Vertebrae: 1. vertebra no. 72 in different views before and after cross sectioning; cranial, ventral, dorsal, lateral, cross sections, and interpretative drawing; 2. vertebra no. 126 in different views before and after cross sectioning; cranial, ventral, dorsal, lateral, cross sections, and interpretative drawing. (c) Teeth; 1. lateral tooth (see (a) = T2), labial; 2. anterior tooth (see (a) = T3), labial; 3. lateral rootless tooth $($ see $(\mathrm{a})=\mathrm{T} 4)$, lingual; 4 . lateral rootless tooth (see $(\mathrm{a})=\mathrm{T} 5)$, lingual; 5. lateral rootless tooth with lateral cusps $($ see $(\mathrm{a})$ = T1), labial. (d) Dermal denticles from the head region. 1-5; first scale type I of the mouth and gills bars-1. posterior, 2. occlusal, 3. occlusal, 4. lateral, 5. basal. 6-7; second scale type II from upon the gills-6. occlusal, 7. lateral. 8-10; third scale type III, all occlusal. 11-12; fourth scale type IV, both occlusal. 


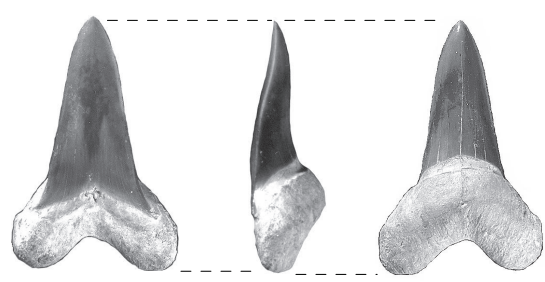

(a)

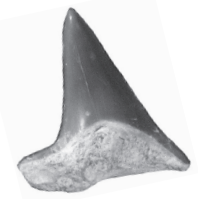

(c)

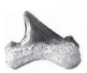

(g)

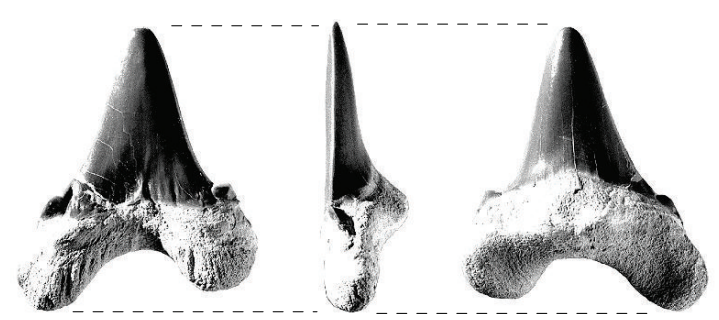

(j)

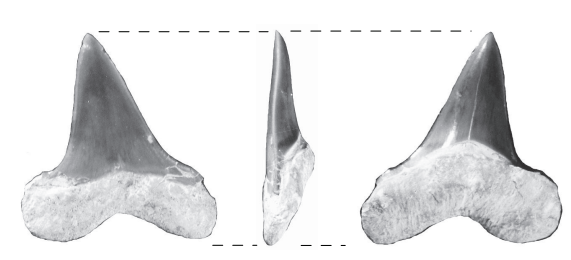

(b)

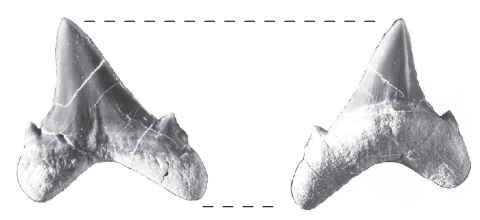

(f)

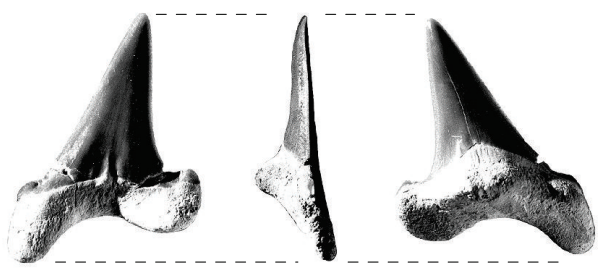

(i)

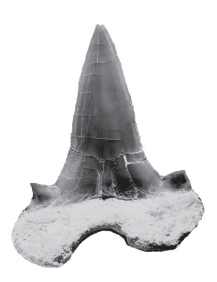

(k)

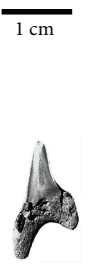

(1)

Figure 6: Teeth of Isurus from different sites of north-western Germany. (a) Lateral tooth of I. denticulatus from the late Turonian of Halle/Westph. (NMB, no. 3916 Foerth-Isurus-1a); labial, lateral, lingual views; (b) anterior tooth of I. denticulatus (skeleton) from the late Turonian of Halle/Westph. (NMB, no. 3916 Foerth-Isurus-1a): labial, lateral, lingual views; (c) lateral rootless tooth of I. denticulatus (skeleton) from the late Turonian of Halle/Westph. (NMB, no. 3916 Foerth-Isurus-1a), lingual view; (d) lateral rootless tooth of I. denticulatus (skeleton) from the late Turonian of Halle/Westph. (NMB, no. 3916 Foerth-Isurus-1a): lingual view; (e) lateral rootless tooth with lateral cusps of $I$. denticulatus from the late Turonian of Halle/Westph. (NMB, no. 3916 Foerth-Isurus-1a): labial view; (f) lateral tooth of I. denticulatus from the late Cenomanian (Chondrites bed, Calycoceras naviculare Zone) of Halle/Hesseltal (EZM Diedrich Hes-1): labial, lingual views; (g) posterior lateral tooth of I. denticulatus from the late Cenomanian (Puzosia event I, Metoicoceras geslinianum zone) of Halle/Hesseltal (WMFNM, no. P.-22024): labial view; (h) lateral tooth of I. denticulatus from the late Cenomanian (Grüne Mergellage, Calycoceras naviculare Zone) of Halle/Hesseltal, (EZM Diedrich Hes-2): labial view; (i) anterolateral tooth of I. appendiculatus from the early Cenomanian (slump in the Mantelliceras dixoni zone) from Halle/Ascheloh (EZM no. Diedrich, Asch-Sel 3): (A) labial, (B) lateral, (C) lingual views; (j) lateral tooth of I. appendiculatus from the early Cenomanian (slump in the Mantelliceras dixoni zone) from Halle/Ascheloh (EZM no. Diedrich, Asch-Sel 4): labial, lateral, lingual views; (k) lateral tooth of I. appendiculatus from the early Cenomanian (slump in the Mantelliceras dixoni Zone) from Halle/Ascheloh (EZM No. Diedrich, Asch-Sel 5): labial view; (1) symphyseal tooth of I. denticulatus from the late Cenomanian (Puzosia event I, Metoicoceras geslinianum zone) from Halle/Hesseltal (WMFNM, no. P.-19918), labial view.

sculptural elements. The maximum length measures $8 \mathrm{~mm}$. A well-developed root has a central foramina.

(iv) A fourth type IV (Figures 5(d) 7-10) is rhomboidal in outline, similar to type one, but has 8 to 9 basal ridges beginning anteriorly on the margin and reaching only the mid-high of the enamel surface. The root is rhomboidal with a basal central foramina.
Meckel's Cartilage. Isolated fragments of calcified cartilage are recognized as being scattered with fragments around the cranial vertebral column. They are not larger than $30 \times 30 \mathrm{~mm}$ and $3 \mathrm{~mm}$ in thickness. The perforate structure is made up of 1-2 $\mathrm{mm}$ thin pore canals radially connected on the surface via a network structure. The origin of the cartilage seems to be cranial. These fragments are coming most probably from the 


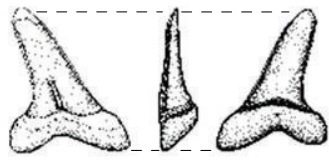

(a)

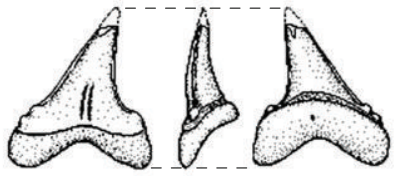

(d)

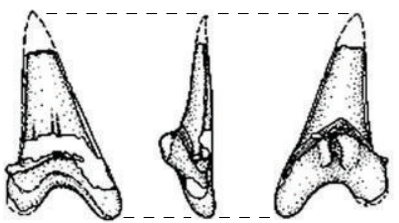

(g)

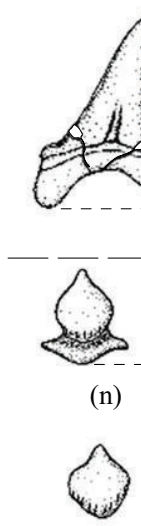

(q) (j)

$-\frac{1}{8}$

mo

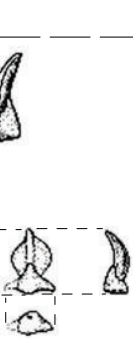

(r)

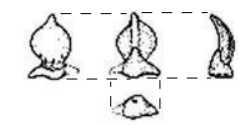

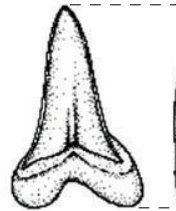

(b)

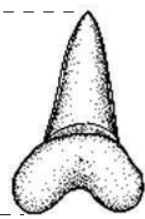

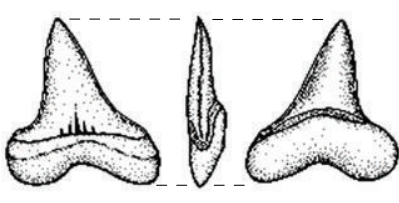

(c)

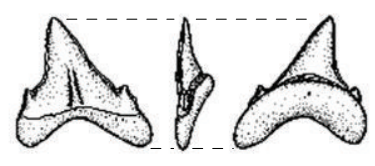

(e)

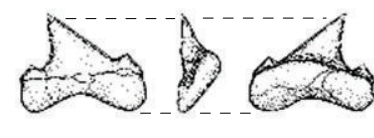

(f)

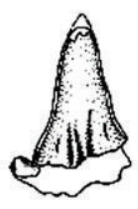

(h)

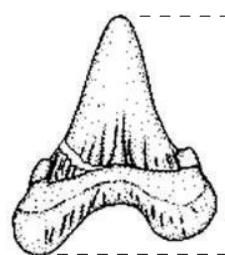

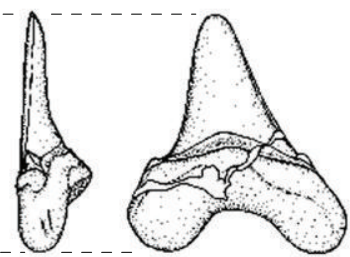

(i)
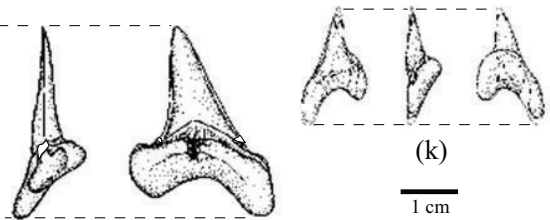

(k)

$\frac{(\mathrm{k})}{1 \mathrm{~cm}}$

FIgURE 7: Interpretative drawings of teeth and dermal denticles of Late Cretaceous Isurus I. appandiculatus (g-j, l, m, s, t); I. denticulatus (b-f, k, n-p, r, u); I. mantellii (a, q, v) (a) Anterolateral tooth, late Santonian, Weiner Esch/Ochtrup (RE no. 551.763.333 A 3868): (A) labial, (B) lateral, (C) lingual views; (b) anterior tooth, late Turonian, Halle/Westph. (NMB, no. 3916 Foerth-Isurus-1a): (A) labial, (B) lateral, (C) lingual views; (c) lateral tooth, late Turonian, Halle/Westph. (NMB, no. 3916 Foerth-Isurus-1a): (A) labial, (B) lateral, (C) lingual views; (d) lateral tooth, late Cenomanian (C. naviculare zone), Halle/Hesseltal (EZM Diedrich Hes-2), labial view; (e) Lateral tooth, late Cenomanian (C. naviculare Zone), Halle/Hesseltal, (EZM Diedrich Hes-1): (A) labial, (B) lingual views; (f) posterior lateral tooth, late Cenomanian (M. geslinianum zone), Halle/Hesseltal (WMFNM, no. P.-22024): (A) labial, (B) lingual views; (g) anterior tooth, early Cenomanian (M. dixoni zone), Halle/Ascheloh (EZM no. Diedrich Asch-Sel 1): (A) labial, (B) lateral, (C) lingual views; (h) anterior tooth, early Cenomanian (M. dixoni zone), Halle/Ascheloh (EZM no. Diedrich, Asch-Sel 2): (A) labial, (B) lateral, (C) lingual views; (i) lateral tooth, early Cenomanian (M. dixoni zone), Halle/Ascheloh, (EZC no. Diedrich, Asch-Sel 4): (A) labial, (B) lateral, (C) lingual views; (j) anterolateral tooth, early Cenomanian (M. dixoni zone), Halle/Ascheloh (EZM no. Diedrich Asch-Sel 3): (A) labial, (B) lateral, (C). lingual views; (k) symphyseal tooth, late Cenomanian (M. geslinianum Zone), Halle/Hesseltal (WMFNM, no. P.-19918): (A) labial, (B) lateral, (C) lingual views; (1) lateral tooth, Aptian/Albian, Poland (redrawn after [21]) lingual view; (m) Lateral tooth, Aptian/Albian, Poland (redrawn after [21]) lingual view; (n) Dermal denticle type I, late Turonian, Halle/Westph. (NMB, no. 3916 Foerth-Isurus-1a): (A) occlusal, (B) back view, (C) lateral, (D) basal views; (o) dermal denticle type I, late Turonian, Halle/Westph. (NMB, no. 3916 Foerth-Isurus-1a): (A) occlusal, (B) back view, (C) lateral, (D) basal views; (p) dermal denticle type I, late Turonian, Halle/Westph. (NMB, no. 3916 Foerth-Isurus-1a): (A) occlusal, (B) back view, (C) lateral, (D) basal views; (q) Dermal denticle type I without root Niobrara Fm (Coniacian to Campanian), USA: (A) occlusal view; (r) dermal denticle type I, late Cenomanian (M. geslinianum zone), Halle/Hesseltal (WMFNM, no. P.-22048): (A) occlusal, (B) posterior, (C) lateral, (D) basal views; (s) dermal denticle type II, late Turonian, Halle/Westph. (NMB, no. 3916 Foerth-Isurus-1a): (A) occlusal, (B) basal, (C) lateral views; (t) dermal denticle type II, late Turonian, Halle/Westph. (NMB, no. 3916 Foerth-Isurus-1a): (A) occlusal, (B) basal, (C) lateral views; (u) dermal denticle type II, late Cenomanian (M. geslinianum zone), Halle/Hesseltal (WMFNM, no. P.-22037): (A) occlusal, (B) basal, (C) lateral views; (v) dermal denticle type II, Niobrara Fm (Coniacian to Campanian), USA: (A) occlusal, (B) lateral views. 
gill bars or the jaws. A clear anatomical position is not visible because of the small disarticulated fragments preservation.

Teeth. Only five large teeth from different locations are preserved. The labial coronal surface of all teeth cusps is flat; the lingual one is ornamented with one to four longitudinal basal and irregular crenulation faults. Lingual's corona is convex and well developed in the anterior tooth. The complete anterior tooth (Figure 6(a)) measures $35.5 \mathrm{~mm}$ in height and $23.1 \mathrm{~mm}$ in width. The cusp is slender and slightly moved from the apex labially. The root is massive and without a clear foramina. Two enamel crenulations are visible on the labial side. Four lateral teeth are present.

(i) The first one is complete and belongs to the upper jaw (Figure 6(b)). Its total length measures $28.2 \mathrm{~mm}$ and the width of the root is $26.6 \mathrm{~mm}$. The crown base is prominent and bright; the root in lateral view is flat but without a clear nutritive foramina. Labially, five enamel crenulations are present.

(ii) A second lateral rootless tooth (Figure 6(e)) has a cusp length of $22.3 \mathrm{~mm}$ and a width of $21.7 \mathrm{~mm}$ at the crown base. Very large triangular lateral cusps are well preserved.

(iii) A third lateral tooth (Figure 6(d)) is rootless as well; $17.5 \mathrm{~mm}$ in height and $13.5 \mathrm{~mm}$ in width at the crown base.

(iv) The last tooth crown (Figure $6(\mathrm{~d})$ ) is $22.0 \mathrm{~mm}$ in height and $22.5 \mathrm{~mm}$ wide at the bright base.

\section{Discussion}

5.1. Global Skeleton Records. Isurus skeletons from the upper Cretaceous are very rare in Europe, especially in the Cenomanian and the Turonian. The herein described I. denticulatus find from Germany (Figure 4) is the oldest skeleton record of this genus. In Italy, another "Cretoxyrhina mantelli" skeleton in the "Senonian" strata (= Coniacian to Santonian) was recovered in historic times [30]. This long articulated vertebrate column (without caudal part) was associated with many rootless teeth (Figure $4(\mathrm{~d})$ ). The figures do not allow deciding whether the roots are stuck in the sediment or are not preserved. A set of 50 teeth and vertebrae of a single individual of "Cretoxyrhina mantelli" and other isolated teeth were found in the "Upper Chalk" (= Coniacian to early Campanian) of Grays in southeast England [31-37]. Skeletons have much better records in the younger ConiacianCampanian strata of Northern America of the Western Interior Seaway (cf. $[6,10-15,18,29])$. Eastman [28] described from there the first nearly complete skeleton of "Cretoxyrhina mantell" from the "Niobrara Group" (= Niobrara Formation, Coniacian-Campanian). This skeleton, housed in the Bayerische Staatssammlung Munich, was destroyed during World War II (pers. com. Wellnhofer). Shimada [6, 10-15, 29] and Shimada et al. [14] published very well-preserved, nearly complete and new skeletons of "Cretoxyrhina mantelli" from the Niobrara Formation, Kansas (North America). Other specimens (a complete skeleton plus another partial one) of Isurus mantelli from the "Selma Formation" (Kansas) are housed in the Museum of Natural History of the University of Kansas (no. 199): they are not figured or described in detail but were mentioned [38]. An associated tooth set was also figured more recently (cf. [39]).

5.2. Vertebrae. One hundred forty-nine vertebrae compose the incomplete vertebral column of the late Turonian isurid of Halle-Foerth compared to the incomplete isurid skeleton counting 205 vertebrae as described by Eastman [28]. He noted an increasing diameter from the first cranial vertebra to the body center, changing at this point to a reduced diameter continuously to caudal. The 218 vertebrae of the most complete specimen of the Niobrara Formation (FHSM VP2187, Figure 4(c), after [13]) are the most informative, even if nos. 6 to 10 caudal vertebrae are missing. A comparison to the German I. denticulatus skeleton demonstrates the missing of 30-40 cranial and the last caudal vertebrae. If the total number of about 225 vertebrae is accepted for this genus generally, then only 149 are present on the new Turonian German I. denticulatus skeleton, about 75 seem to be lost. Because of variations in body sizes between the Turonian and Niobrarian skeletons (cf. ontogenetic variability in [29]), the total number of vertebrae can not be precised in $I$. denticulatus yet. The length of the Eastman specimen was given as $700 \mathrm{~cm}$ in length [28]. The most complete specimen FHSM VP-2187 (Figure 4(c)) is about $550 \mathrm{~cm}$ in length (cf. [13]). The skeleton of Halle-Foerth reaches a maximum length of $400 \mathrm{~cm}$ if the total vertebrae amount of about 225 is used herein.

Isolated vertebra and column fragments of the upper Cretaceous Isurus have been found worldwide. Another column part from the Turonian locality Halle-Foerth found in the Hyphantoceras event (deposited in the WMfNM) and another one housed in the GPIM (consisting of 5 to 9 partly articulated vertebrae) indicate more abundant articulated skeletons also for German sites. In the Cenomanian of Russia, isolated vertebrae were described as "Alopias siwerianus" or "Otodus obliquus" and as unidentified selachian vertebrae (cf. [40]). Also, a large Isurus vertebra from the Middle Turonian greensand of north-western Germany was figured [17]. It is very similar in size and shape to the vertebra described herein for the upper Cretaceous Isurus with its asterospondylic selachian vertebra type, which is present similar in both Isurus and Lamna (e.g., [1]). Mantell [36] figured also a large asterospondylic vertebra from the "Upper Chalk" of England that he assigned to I. mantelli. Hasse [41] figured another similar sectioned vertebra. All those single vertebrae are identical in characters to those of the new German Turonian Isurus skeleton. They are flattened ( $\max 2 \mathrm{~cm}$ thick), up to $6 \mathrm{~cm}$ in diameter, are in cross-section asterospondylic, and have similar haemal and neural arch groves which is demonstrated herein on the internal structures of two sectioned vertebrae (nos. 72 and 148, Figure 5(b)). Finally, those are identical in structures to a sectioned vertebra from the extant Isurus oxyrinchus Rafinesque (cf. [7]) and close to the extinct Lamna appendiculata from the Niobrara Formation of North America (cf. [38]). However, the vertebrae of the Turonian Isurus are not useful for further separation of Isurus from 
Lamna, but from other shark genera, which was already discussed (e.g., $[1,29])$.

5.3. Cartilage. The comparison of fossil cartilage (or shagreen) fragments of Isurus with different Late Cretaceous (Cenomanian-Campanian) skeletons proves again identical structures in the new Turonian I. denticulatus skeleton and in the North American I. mantelli skeleton described by Eastman [28]. Under microscope, the cartilage fragments, which are from the cranial region (cf. Figure 4), expose on the surface netlike perforating canals. Also, the cartilage is macroscopically not genus or species diagnostic.

5.4. Dermal Denticle Types. Dermal denticles of the Turonian I. denticulatus skeleton cranial area, isolated scales of the late Cenomanian strata of Halle-Hesseltal (northwest Germany), and scales connected to cartilage of a skull fragment from Gove County (Kansas, USA) in the Smoky Hill Chalk of the Niobrara Fm (late Coniacian) are compared to recent Lamna and Isurus (see denticle photos in $[2,5]$ ). REM figures of dermal scales of $I$. mantelli are lacking, although denticles were described from skeleton remains [13]. The first well description of I. mantelli skeleton dermal denticles by Eastman [28] was not recognized by many authors describing isolated "Cretoxyrhina" remains. He described a couple centimetres in size connected shagreen fragments and many well-preserved dermal scales, including two different types, which he presented with anatomical positions of the skull region. His first described and figured dermal denticle type as being less than $0.5 \mathrm{~mm}$ and well separated into the enameloid rhomboidal surface, having clear and sharp parallel ridges. The root possesses a central foramina. The same scale type was also described for the same species I. mantelli, but was, as mentioned, not figured (cf. [13]), which is figured herein (Figure $7(\mathrm{v})$ ), isolated from the cartilage of a fragmentary skull from the Niobrara Formation. This type (Figure 7(v)) has the same shape such as isolated denticles from the Chondrites bed (C. naviculare Zone, late Cenomanian) of Halle/Hesseltal (cf. [27], Figure 7(u)). This denticle type, always found in the skull region of upper Cretaceous Isurus skulls/skeletons, is also present in I. denticulatus (cf. REMphotos, Figures 5(d) 6 and 7(s)-7(t)). A second denticle type from the German I. denticulatus skeleton (Figures 5(d) 1-5 and $7(\mathrm{n})-7(\mathrm{p}))$ was described but not figured by Eastman [28] nor by Shimada [13]. The material extracted from cartilage fragments of the Gove County I. mantelli cranial shagreen specimen (Figure 7(q)) is similar to the second, drop-shaped, dermal denticle type of I. denticulatus and to an isolated scale from the Chondrites bed (C. naviculare zone, late Cenomanian) of Halle/Hesseltal (Figure 7(r)). Eastman [28] mentioned a $1 \mathrm{~mm}$ small denticle with an unsculptured enameloid surface, but he did not figure a clear outline. Maybe this type can be referred to a third denticle type found similar at the I. denticulatus skeleton (Figure 5(d) 11-12). The fourth scale type (Figures 5(d) 8-10) of the I. denticulatus skeleton is different from the photographed dermal skeleton of the modern Lamna nasus and Isurus oxyrinchus (cf. REM photos of modern species in [5]). This might provide new systematic information. However, the most important new character for the revision arguments comes from the cranial dermal denticles. At minimum, two dermal scale types of the Late Cretaceous I. denticulatus skeleton have exactly the same shape as those of I. oxyrinchus (cf. [5]) which are from the oral cavity and gills. After REM, photos of [5] those cranial areas are covered by small, densely crowded, leafshaped scales which have a short cusp and are completely smooth (herein $=$ type 2 , cf. Figure 5(d) 1-5). The cusps are posteriorly pointed (cf. [5, pl. 20, Figure M1]). Those only for Isurus characteristic scales, are found similar in shapes on juvenile and adult individuals, which are therefore constant in their morphology during ontogeny (cf. [5]). The constant and consistent shape is a plesiomorphic character dating back at minimum to the early Cenomanian, as demonstrated in the German fossil Late Cretaceous record (cf. Figures 7-8). Another type (herein type 1), small rhomboidal, with 7-9 parallel ridges and ornamented scales was also figured by Reif (cf. [5, pl. 21, Figure H2]) for I. oxyrinchus on its gill areas. The only difference of those denticle shapes to the Late Cretaceous material of Isurus is the amount of the parallel ridges, which, however, fall within a variability or demonstrate a slower evolutionary change, as in the dentition. Juvenile individuals of I. oxyrinchus have up to three such ridges, whereas adults ( $220 \mathrm{~cm}$ in length) have up to 5 (cf. [5, pl. 21, Figure H2]), and therefore, an evolutionary trend seemed to be excluded. However, there are small differences in those denticle types of Cretaceous and Modern Isurus. In the $400 \mathrm{~cm}$ long "adult" I. denticulatus skeleton, up to seven ridges are present on the scale surfaces (Figures 5(d) 6 and $7(\mathrm{~s})-7(\mathrm{t})$ ). The same ornamentation number is found in the material from the Niobrara Formation (Figure 7(v)) and on isolated scales from the late Cenomanian of Halle-Hesseltal (Figure 7(u)).

5.5. Tooth Record and Evolutionary Trend. The teeth of the upper Cretaceous Isurus were described very often, but because of different morphologies, they were referred to different species or genera. Tooth crowns by Mantell [35] described as "Squalus zygaena" (pl. 32, Figures 26, 28; non $4,7,8,10)$ seem to belong to I. denticulatus or I. mantelli. Such rootless crowns are not diagnostic, nor is the presence of nonprominent lateral cusps in lamnid shark tooth morphology, in which genera are based mainly on those characteristics. Therefore, the taxon name Squalus zygaena must be considered as a nomen nudum. The typical lamnid tooth is flanked by nonprominent lateral cusps such as in the Cenomanian and Turonian teeth of I. denticulatus. Many authors also consider this feature as typical for Lamna (or Cretolamna). The result was a separation into the species Cretolamna appendiculata and Otodus semiplicatus and other genera Macrorhizodus and Isurolamna, in which the latter is also seen herein as being simply Isurus.

Cenomanian-Turonian. Reuss [42], Geinitz [43-45], and Fritsch [46, 47] described and figured isolated teeth of "Oxyrhina mantelli" from the Cenomanian of the Elbe Sandstone Mountains in Germany and Czech Republic. The teeth figured by Reuss [42, pl. 3, Figures 1-6] are considered here as anterior and lateral teeth of I. denticulatus. One lateral tooth is flanked by the typical lateral cusps. Also, the 


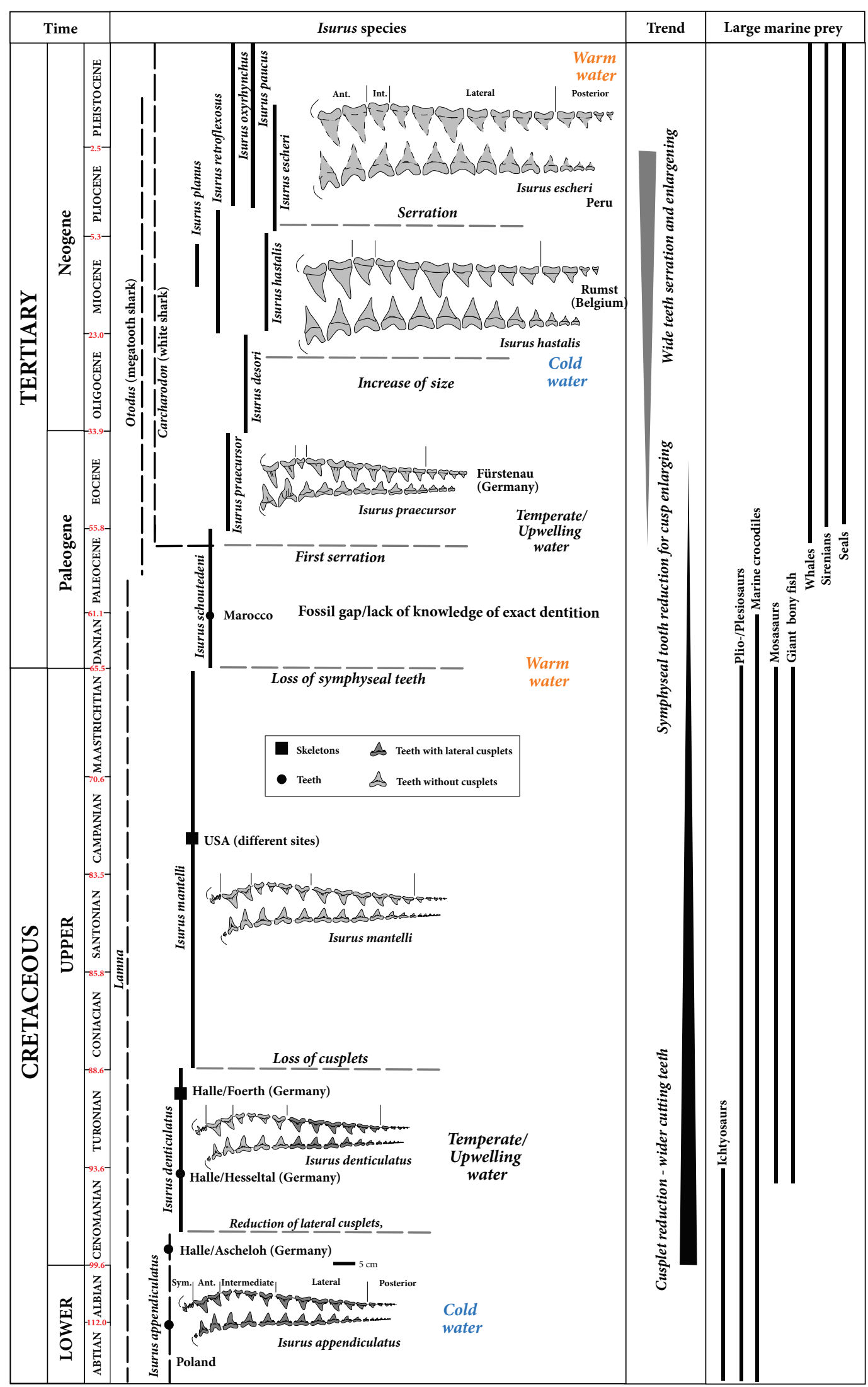

FIGURE 8: Stratophylogenetic trend within the genus Isurus during the Cretaceous and Tertiary. The cusplets were reduced from anterior to posterior changing from a catching to cutting type dentition (see also [11, 12]). Serrations were developed twice to Carcharodon and Isurus escheri (after [3]). 
teeth that Reuss [42] described as "Otodus appendiculatus" (pl. 3, Figures 24, Cenomanian-Turonian, and 29) and " $O$. semiplicatus" (pl. 3, Figures 21, 24, 27, and 29) are considered here as lateral cusped teeth of I. denticulatus. Dixon [33] figured the teeth of $I$. mantelli from the Cretaceous of England under the name "Lamna acuminata." Fischer [48, pl. 2, Figure 43] identified an anterior lateral tooth from the Cenomanian/Turonian of Strehlen, Germany, as "Oxyrhina mantelli." Roemer [49, pl. 36, Figures 3-5] described two anterior teeth (one upper and one lower tooth) and an anterolateral one, all without cusplets, as belonging to "Oxyrhina mantelli." Geinitz [43-45] mentioned and figured Turonian anterior and lateral teeth from the Plänerkalk (Turonian) of Strehlen, as "Oxyrhina mantelli." Teeth from the upper Cretaceous of USA described and figured as "Oxyrhina extent" by Leidy [50] are considered here as belonging to I. mantelli. Another upper jaw lateral tooth without lateral cusps is figured as "Oxyrhina mantelli" by Fritsch [46, text Figure 12] that comes from the "Isarschichten" (Turonian) of Bohemia, Czech Republic. Based on teeth from the upper Cretaceous of England (considered as belonging to Isurus here), Woodward [31, 32] created two species. "Oxyrhina mantellii" and "Lamna macrorhiza." The first lacks lateral cusps, and the latter (today "Macrorhizodus macrorhiza") has exposed lateral cusplets. The latter is also similar to the early (Albian-Lower Cenomanian) Isurus tooth type (cf. Figure 8). Cenomanian teeth from southeast England, figured and identified as "Lamna appendiculata" by Woodward [37, pl. XLIV, Figure 6, 7, non 3-5], are considered here as lateral teeth with lateral cusps of I. appendiculatus or I. denticulatus. Another tooth from the early Cenomanian of England figured by Woodward [37, pl. XLIII, Figure 12] is similar to material from the early Cenomanian of Halle-Ascheloh (Germany) as described here. It is not clear whether this nonstratified (Cenomanian-Turonian) tooth of the same plate (Figures 11 and 13) belongs to I. denticulatus. Even if so, it has very small lateral cusps (as in the early Cenomanian $I$. appendiculatus teeth from Halle/Ascheloh, cf. Figure 8).

Williston [51] was the first to consider the teeth of "Oxyrhina mantelli" as belonging to Isurus (= I. mantelli), a consideration followed by Witzke [52] based on specimens from the Late Cretaceous of USA. Lériche [53, pl. 3, Figure 49] considered a small lateral tooth from the A. plenus Zone (latest Cenomanian) as belonging to "Oxyrhina mantelli." Additional teeth from the Cenomanian and Turonian described as "O. manteli" $[54,55]$ are considered here to belong to $I$. denticulatus. Another typical but incomplete tooth of Isurus from the green sandstone facies (Cenomanian/Turonain) of the Wevelsburg in the Muenster Basin was figured by Jordan [56], indicating its facies breaking occurrence in coastal to shallow marine temperate and upwelling influenced regions [17].

Glickman [8, pl. 1, Figures 1-17] created the Cenomanian species "Isurus denticulatus" based only on isolated and nonsymphyseal anterior/lateral teeth of Czech Republic. The middle lateral to posterior teeth that he figured show lateral cusps but not the anterior ones. This is identical to the German Isurus skeleton. Later, Glickman [9] created the taxa "Cretoxyrhina" and "Isurus denticulata" from the same layers based on their separation only in its arguments by the "presence of lateral cusps on the lateral teeth," which represent after the herein results only different jaw positions within I. denticulatus (Figure 8).

Anterior teeth of I. denticulatus from the Atarque Sandstone Member (Middle-Turonian) were identified by Wolberg $[57,58]$ as belonging to "C. appendiculata." He also identified anterior tooth with lateral cusps from there as belonging to I. denticulata. Longbottom and Patterson [34] figured a lateral tooth without lateral cusps, from the Campanian of England, as "Cretoxyrhina mantelli." A small lower and anterior tooth from the Turonian of Texas, without lateral cusps, was described as "Cretoxyrhina mantelli" by Cappetta [1]. The tooth figured by Werner [59] is not preserved enough to identify it as I. mantelli but is surely of the genus Isurus. Late Cenomanian teeth of "Cretoxyrhina mantelli" and "Cretolamna woodwardi" described by Williamson et al. [60] demonstrate again the problem of the presence or absence of lateral cusps as a diagnostic character at all.

All North American Coniacian-Campanian Isurus skeletons and tooth sets help reconstruct well the dentition of I. mantelli (cf. [12]), which was finally used herein for a preliminary reconstruction of the dentition of few younger species of I. denticulatus (cf. Figure 8). Those ConiacianCampanian $I$. mantelli teeth are all without lateral cusps (cf. [1, 13, 28, 50, 51, 61-66]), which allow to separate I. appendiculatus, I. denticulatus from I. mantelli only on complete tooth sets.

5.6. Stratophenetic and Evolutionary Trend within the Isurus Lineage. The genus Isurus seems to evolve, such as many Neoselachians (cf. [1]), within the late Early Cretaceous, and survived the Cretaceous/Tertiary boundary, which is seen herein contraversionally to other authors (e.g., [10]), whereas a fossil gap or missing abundant shark tooth/skeleton record is present within the Maastrichtian-Danian. A stratophenetic trend is proposed for Isurus during the Aptian to the Campanian (late Early to late Late Cretaceous) based on tooth morphology (cf. [12]) (Figure 8), in which further preliminary evolutionary trend is added for the Tertiary within the genus Isurus, which seem to split in several species [1].

Aptian-Albian. The first records of Isurus are in the Aptian/Albian (uppermost Early Cretaceous) with a species of lamnid-type teeth, with lateral cusplets on all anterior to posterior teeth. The root was described as plesiomorphic which has no nutritive cleft or foramen. This form is dated from the Aptian to early Cenomanian. From the middle to late Albian (Albian phosphorite beds) of Poland, Marcinowski and Radwanski [67] figured and identified an anterior rootless tooth without lateral cusps as belonging to "Oxyrhina mantelli" and a lateral tooth with roots and lateral cusps as belonging to "Otodus appendiculatus." These teeth are similar to those of I. appendiculatus and to those of the midCretaceous of Kazakhstan [21].

Early Cenomanian. Teeth of "C. mantelli" from the early Cenomanian of Halle/Ascheloh, mentioned by Müller and Diedrich [4], are figured here now (Figures 6(i)-6(k) and 
$7(\mathrm{~g})-7(\mathrm{j}))$ : two anterior but partial teeth (Figures $7(\mathrm{~g})-7(\mathrm{~h})$ ) have lateral cusps. Sometimes a nutritive cleft seems to be present but not well developed (Figure $7(\mathrm{~g})$ ). Lateral teeth show no nutritive cleft but diagnostic, extremely bright lateral cusps (Figures 6(j) and 7(i)). Roots are sometimes labially ornamented with longitudinal ridges (Figure 7(i)). This material is very typical of Isurus from the Albian to early Cenomanian. Anterior teeth and lateral teeth with lateral cusps sometimes have a nutritive cleft. Both characteristics are present in other lamnidae and correspond to a plesiomorphic character (cf. $[1,6])$. Some lateral and symphyseal teeth from the late Cenomanian (C. naviculare and M. geslinianum Zone) of Halle/Hesseltal (Figures 6(f)-6(h), 7(d)-7(f) and $7(\mathrm{k})$, [23]) fall into the typical variety of the tooth morphology of I. appendiculatus, whose separation must have occurred during the Cenomanian-Turonain boundary. Other rare Cenomanian "Cretoxyrhina" teeth from Northern America were described but often incorrectly referred to " $C$. mantelli" $[14,68]$.

Middle Cenomanian. The anterior teeth with couplets seem to start to dissappear in the middle Cenomanian (Figure 8).

Late Cenomanian. Isurus material is rare from that time globally, and the important anterior teeth are still not preserved. In the late Cenomanian, anterior teeth seem to be partly with and partly without lateral cusps and show a typical isurid root. Sometimes a nutritive cleft is present. All lateral teeth from the early to late Cenomanian are flanked by lateral cusps. In contrast, lateral cusps are absent at the anterior and anterior lateral teeth.

Upper Turonian. In the late Turonian, lateral cusps of the anterior teeth have already been reduced (Figure 8) as shown by the anterior tooth of the new skeleton of I. denticulatus.

Coniacian-Santonian. From the lower Coniacian to the upper Santonian, the lateral cusps, completely reduced, are only rudimentary rarely present, a character considered as plesiomorphic [10]. New teeth from the Late Santonian of the Weiner Esch near Ochtrup (northwest Germany) show also no lateral cusps at all anterior to posterior teeth ([26], Figure 7(a)).

Campanian. Also, the material of the Coniacian to Campanian of the Niobrara Formation of USA, which are referred to as I. mantelli (cf. [10] = "Cretoxyrhina mantelli"), has no lateral cusplets.

Maastrichtian-Palaeocene. Following the stratophenetical approach adopted here, Isurus continued with the Maastrichtian to Late Paleocene (Thanetian) with the species $I$. schoutedeni found in Morocco, northern Africa [69, 70].

Middle Eocene. Including herein also the newest Eocene finds from northern Germany [16] there is no need to separate Cretaceous from Tertiary Isurus genera, only species (Figure 8). Numerous recently discovered teeth of Isurus praecursor allow a preliminary reconstruction of the Early to Middle Eocene Isurus dentition (Figure 8), based on the wellknown dentition of younger species.
Oligocene. I. desori (Sismonda) is the species from this period that is well known in Europe and also northern Germany (e.g., $[1,71]$, Figure 8 ).

Miocene. I. planus (Agassiz), I. xiphodon (Agassiz), (Miocene), I. retroflexus (Agassiz), I. hastalis (Agassiz), and I. escheri (Agassiz), (Miocene-Pliocene) developed in the Miocene, whereas a serration developed from I. hastalis to $I$. escheri, which is not seen in new discussions as the "ancestor" of the modern white sharks [3]. I. escheri was found only on the Pacific along the South American coastline with extinction in the Pleistocene (Figure 8).

Pliocene to Modern. I. oxyrinchus (Rafinesque) and I. paucus (Guitart Manday) are the extant species (e.g., [5]).

5.7. Coevolutionary Prey and Tooth Morphology Change. Shimada [6] described homologies in Cretaceous lamnid dentitions and their evolution, but did not include the older forms (Cenomanian/Turonian), neither the Tertiary ones. The change in tooth morphology of Isurus is obviously correlated with a change in feeding habits and prey presence, as already newly described for the Tertiary large shark record (cf. [3]). Isurus seems to have evolved already in the late Early Cretaceous. In the Albian to the lower Cenomanian, the tearing-type dentition with cusps was present which separate herein the first species from I. appendiculatus (Figure 8), which was very close to Lamna in its dental characters (cf. also [6]). This dentition with cusplets was adapted best to the fish hunting (cf. $[1,6]$ ). Even largest fish of the upper Cretaceous, such as Xiphactinus, was swallowed and consumed completely, which is demonstrated well by the stomach content of one I. mantelli skeleton (Figure 4(b)) (cf. $[18,19])$. Also, even larger suspension-feeding giant fish like Bonnerichthys (cf. [72]) was possibly a prey. This fish was globally distributed together with its top predator, Isurus, in the northern hemisphere and was also common in the ProtoNorth Sea Basin of Europe (cf. Figure 3).

In the basal Late Cretaceous marine large reptiles were present with the last ichthyosaurs, which occurred rarely during the lower to upper Cenomanian also in Europe, the Proto-North Sea Basin [73, 74]. The few finds indicate this reptile group to be less important as prey and motor for coevolutionary tooth change within Isurus. Important plio-/plesiosaurs were reduced at that time already in their biodiversity $[73,74]$ and disappeared with most groups during Turonian [75-82]. In the Turonian, Polyptychodon was especially distributed and was also found in the Proto-North Sea Basin of Europe at some sites [79-82]. This marine reptile group continued with Elasmosaurus long-necked forms into the Maastrichtian [83]. However, those reptiles, which also are demonstrated to have large shark bite damages on bones [18], were most probably also not the motor of prey-predator coevolution, because already in the Jurassic, when their biodiversity was the best, no such evolutionary adaptation is seen in shark evolution yet. Also, marine crocodiles, another possible food source for large shark Isurus, were present during the Cretaceous but seem to have played again no role for the coevolutionary trend. 
The most obvious correlation is found within the Cretaceous "whale-like" mosasaurs, and Isurus as its top scavenger, which is proven by bitten mosasaur vertebrae and bones $(\mathrm{Cli}$ dastes, cf. [18, 84, 85]). Mosasaurs developed with first smaller forms in the late Cenomanian, diversified in the Turonian [86], with larger (time of I. denticulatus), and radiated especially in the Coniacian-Campanian with largest forms (time of I. mantelli) in maximum within the Maastrichtian where they finally disappeared globally at the Cretaceous/Paleogene boundary [87]. During the Turonian-Campanian, the time of maximum mosasaur biodiversity, which is seen as the main scavenging prey for upper Cretaceous Isurus, the tooth morphology changed again within Isurus already in the middle Turonian to a full cutting-type without any lateral cusplets (cf. [11, 12], Figure 8), which continued into the Maastrichtian ([69], time of I. schoutendeni). The extinction of large marine reptiles (especially mosasaurs) at the end of the Late Cretaceous (Figure 8) explains best a new radiation within Isurus, which was believed to be the beginning of Isurus by many authors, such as $[1,6]$, that had to adapt again to prey, but this time on marine mammals such as whales, sirenians, and seals that all evolved already in the Paleocene/Eocene (Thanetian, Ypresian, e.g., [3]). It seems, from the larger I. schoutendeni, that I. praecursor evolved around the Cretaceous/Paleogene boundary which characters in tooth morphology are most close. Their gap in well knowledge seems to relate to a fossil gap, and possibly this is driven by climate change and ocean water temperature changes, partly by upwelling influence.

5.8. Paleocurrent Water Temperature and Climate of Isurus. The trend within Isurus is obviously also driven by paleoclimate (cf. [3]). The oldest forms appear in cold water regions and lived also in upwelling influenced oceans (Figure 8). Isurus was no warm water form, obviously, which might explain their reduction in some ocean areas, especially during the warmer Maastrichtian periods. Finally this explains then why I. schoutendeni is found in Morocco (and not anymore at other "classical older Isurus locality" regions globally), in which northwestern African coast was under upwelling influence. A similar relationship of paleocurrents and water temperature trends was recently found in the "white sharks" [3], which are believed to have evolved from Isurus, and which were in the past also temperate to upwelling adapted large sharks, instead Otodus (= megatooth shark) was the warm water top predator that became extinct in global cooling of the Pleistocene (cf. [3]).

\section{Conclusions}

The similarities of the asterospondylic vertebra, cartilage, dermal denticle morphology in the cranial region, and tooth morphology between upper Cretaceous I. appendiculatus, I. denticulatus, I. mantelli, and Modern I. oxyrinchus indicate that the genus "Cretoxyrhina" is a junior synonym of Isurus. The Cretaceous genus "Cretoxyrhina" was created based on tooth morphology and presence, absence of cusplets on teeth from Cenomanian deposits of Europe (southern Proto-North Sea Basin) by Glickman $(1957,1964)$. Cretoxyrhina is revised here and synonymized with Isurus, which origin is believed to have started such as other Neoselachians already in the late Early Cretaceous. Tooth morphology changed strongly within this genus. The taxonomy is only to understand by including Cretaceous and Tertiary forms globally. This revision of one of the largest sharks Isurus (= mackerel shark) is based on similar and plesiomorphic shagreen denticle types of the head region, which are strongly different in Isurus and Lamna, in extinct and extant species. The dermal denticles do not change during the Cenomanian to the Campanian. All the fossil upper Cretaceous and modern extant Isusus species have the $5 \mathrm{~mm}$ small rhomboidal cranial dermal denticle type on the gill areas, with many more enameloid parallel ridges in adult Cretaceous Isurus than in recent adults of $I$. oxyrinchus with a trend to few ridge reduction within the evolution. All the Late Cretaceous and extant Isurus species possess a second, up to $2 \mathrm{~mm}$ drop/leafshaped denticle type in the mouth to gill bar areas, also not present with such forms in Lamna. A reducing of the lateral cusps of the teeth started anteriorly during the Cenomanian; also, the crown base became more prominent, especially on the anterior teeth. Cartilage and vertebrae, in contrast, do not appear to change in their morphology as in modern species of Isurus, which is similar to Lamna. The possible monophyletic series of the Cretaceous Isurus starts in the late Early Cretaceous (pre-Albian), while the early forms, between Albian to late Cenomanian, still show plesiomorphic characters with the lamniform sharks, especially the asterospondylic vertebra and tooth morphology: the teeth possess cusplets on anterior to lateral and rarely on anterior teeth, a possible nutritive cleft and central foramina at the root base (I. appendiculatus). It is rectangular and flat within the early to middle Cenomanian Isurus. In the latest Cenomanian to late Turonian, I. denticulatus Glickman, 1957 has reduced and sometimes absent cusplets on the anterior teeth and first lateral teeth-which gave confusing to separate both to two different "species." The stratigraphically younger valid and by many skeletons best known I. mantelli Agassiz, 1833 from the Coniacian to Campanian has no cusplets at all anymore, such as the Maastrichtian I. schoutendeni. During the Cretaceous evolution of Isurus, the tooth morphology changed from a catching to a cutting-type with a reduction of the lateral cusps and the presence of broad tooth cusp bases. This tooth morphology change correlates mainly with the mosasaur evolution and biodiversity, whereas Isurus seem to have specialized to scavenge on their carcasses globally. With the extinction of mosasaurs, this had a strong impact on a new "wave of the Isurus" evolution, which was seen in former times as the "beginning of Isurus evolution." This indeed continued over the Cretaceous/Paleogene boundary, and within Isurus; two new coevolutionary dentition changes resulted from the adaptation to new marine prey, whales, sirenians, and seals. Within the Paleocene Isurus, developed a first serrated new form, which was the beginning of the real white sharks. Possibly from the Eocene I. praecursor the Miocene I. hastalis developed, which enlarged in another trend only its teeth. From this, within Isurus, a second serrated form developed with I. escheri in the Pacific only, which became extinct in the Pleistocene. Also those serration 
evolution trends are correlated with waves and biodiversification of marine mammal prey. In total, there are strong tooth modifications within Irurus, cusplet appearing/disappearing, crown enlarging, and serration-as coevolutionary trends to marine reptile/mammal prey evolution, whereas logically the shagreen and other skeletal characters stay plesiomorphic.

\section{Abbreviations \\ EZM: $\quad$ ErdZeitMuseum Borgholzhausen (Germany) \\ FHSM: $\quad$ Fort Hays State University, Sternberg Museum of Natural History, Hays (USA) \\ GMUP: $\quad$ Museo Geologico della Università, Pavia (Italy) \\ GPIM: Geological-Paleontological Museum of the University of Münster \\ KUVP: University of Kansas Museum of Natural History, Lawrence (USA) \\ NMB: Museum Natur und Mensch Bielefeld, (Germany) \\ RE: $\quad$ Ruhrlandmuseum, Essen (Germany) \\ WMfNM: Wesfälisches Museum für Naturkunde Münster.}

\section{Conflict of Interests}

The author declares that there is no conflict of interests regarding the publication of this paper.

\section{Acknowledgments}

The author is indebted to the I. denticulatus skeleton excavator Mr. M. Plesker, quarry owner Mr. F. Foerth and Mr. S. Schubert for the preparation. The author thanks the following persons for their help during collections visits and for loans of specimens: Dr. M. Büchner Naturkundemuseum Bielefeld gave access to the skeleton; Material of the Smoky Hill Chalk, Niobrara Formation from Gove Country (dermal denticles, teeth, and cartilage) was collected by Dr. M. Everhart, Fort Hays State University, Sternberg Museum of Natural History in Hays (USA). He kindly sent this material and photos from the Museum's collection. He also reviewed the first paper. A second version was critically checked by Dr. J. S. Steyer. A few late Santonian selachian tooth findings from Weiner Esch near Ochtrup (coll. Hilpert) were loaned by Mr. Scheer of the Ruhr Mmuseum Essen. Some Turonian vertebrae remains were studied in the Geological-Palaeontological Museum of the University Münster, for which the author has to thank Dr. M. Bertling. The vertebrae were sectioned and casted by M. Brinkmann of the Preparation laboratory of the GeologischPaleontologische Museum of the University Münster. The author thanks finally $\mathrm{H}$. Felker who arranged a first middle Eocene I. praecursor jaw dentition with his collected material, which was used for the reconstruction.

\section{References}

[1] H. Cappetta, "Chondrichtyes II. Mesozoic and Cenozoic Elasmobranchii," in Handbook of Paleoichthyology, vol. 3, p. 193, Gustav Fischer, New York, NY, USA, 1987.
[2] L. J. V. Compagno, "FAO species catalogue. Volume 4. Parts 1 and 2: sharks of the world," FAO Fisheries Synopsis, vol. 125, no. 4, pp. 1-655, 1984.

[3] C. Diedrich, "White and megatooth shark evolution and predation origin onto seals, sirenians and whales," Natural Science, vol. 5, no. 11, pp. 1203-1218, 2013.

[4] A. Müller and C. Diedrich, "Selachier (Pisces, Chondrichtyes) aus dem Cenomanium von Ascheloh am Teutoburger Wald (NRW, NW-Deutschland)," Geologie und Paläontologie in Westfalen, vol. 20, pp. 1-105, 1991.

[5] W. E. Reif, "Squamation and ecology of sharks," Courier des Forschungsinstitutes Senckenberg, vol. 78, pp. 1-255, 1985.

[6] K. Shimada, "Dental homologies in lamniform sharks (Chondrichthyes: Elasmobranchii)," Journal of Morphology, vol. 251, no. 1, pp. 38-72, 2002.

[7] C. S. Rafinesque, Caratteri di Alcuni Nuovi Generi e Nuove Specie di Animali e Piante Della Sicilia, Con Varie Osservazioni Sopra i Medisimi, Part 1, pp. 1-69; Part 2, pp. 71-105, Sicilia, Palermo, Italy, 1810.

[8] L. S. Glickman, "About the systematic importance of the lateral cusps at selachian teeth of the families Lamnidae and Scapanorhynchidae," Akademia Nauk UDSSR, vol. 1, pp. 103-109, 1957 (Russian).

[9] L. S. Glickman, "Class Chondrichthyes, subclass Elasmobranchii," Akademia Nauk SSSR, vol. 11, pp. 196-237, 1964 (Russian).

[10] K. Shimada, "Stratigraphic record of the late Cretaceous Lamniform Shark, Cretoxyrhina mantelli (Agassiz), in Kansas," Transactions of the Kansas Academy of Sciences, vol. 100, pp. 139149, 1997.

[11] K. Shimada, "Jaws of the Upper Cretaceous shark Cretoxyrhina mantelli from western Kansas," Geological Society of America Abstracts with Programs, vol. 25, p. A58, 1993.

[12] K. Shimada, "Dentition of the Late Cretaceous lamniform shark, Cretoxyrhina mantelli, from the Niobrara Chalk of Kansas," Journal of Vertebrate Paleontology, vol. 17, no. 2, pp. 269-279, 1997.

[13] K. Shimada, "Scales of the Late Cretaceous shark, Cretoxyrhina mantelli, from Western Kansas," Journal of Vertebrate Paleontology, vol. 14, p. 46, 1994.

[14] K. Shimada, S. L. Cumbaa, and D. van Rooyen, "Caudal fin skeleton of the Late Cretaceous shark, Cretoxyrhina mantelli (Lamniformes: Cretoxyrhinidae) from the Niobrara Chalk of Kansas," Bulletin of the New Mexico Museum of Natural History and Science, vol. 35, pp. 185-192, 2006.

[15] K. Shimada, "Skeletal anatomy of the Late Cretaceous shark, Cretoxyrhina mantelli," Journal of Vertebrate Paleontology, vol. 15, p. 53A, 1995.

[16] C. Diedrich, "Early Eocene (Lutetian) coastal shark-rich palaeoenvironments of the southern European North Sea Basin-the marine Fürstenau Fm biodiversity and their earliest white shark ancestors," International Journal of Oceanography, vol. 2012, Article ID 565326, 22 pages, 2012.

[17] C. Diedrich, "Stomach and gastrointestinal tract contents in Late Cenomanian (Upper Cretaceous) teleosts from Black Shales of Germany and analysis of fish mortality and food chains in the upwelling influenced Pre-North Sea Basin of Europe," New Mexico Museum of Natural History and Science Bulletin, vol. 57, pp. 241-254, 2012.

[18] K. Shimada, "Paleoecological relationships of the Late Cretaceous lamniform shark, Cretoxyrhina mantelli (Agassiz)," Journal of Paleontology, vol. 71, no. 5, pp. 926-933, 1997. 
[19] K. Shimada and M. J. Everhart, "Shark-bitten Xiphactinus audax (Teleostei: Ichthyodectiformes) from the Niobrara Chalk (Upper Cretaceous) of Kansas," The Mosasaur, vol. 7, pp. 35-39, 2004.

[20] F. Bassani, "Colonna vertebrale di Oxyrhina mantelli, Agassiz, scoperta nel calcare senoniano di Castellavazzo nel Bellunese," Memorie Della Società Italiana Delle Scienze, vol. 4, pp. 1-85, 1888.

[21] A. Radwanski and R. Marcinowski, "Elasmobranch teeth from the mid-Cretaceous sequence of the Mangyshlak Mountains, Western Kazakhstan," Acta Geologica Polonica, vol. 46, pp. 165$169,1996$.

[22] U. Kaplan, "Oberkreide im Teutoburger Wald (NW-Deutschland), Teil 1: Turon und Coniac im Steinbruch des Kalkwerkes Foerth, Halle/Westfalen," Berichte des Naturwissenschaftlichen Vereins von Bielefeld und Umgegend, vol. 32, pp. 125-160, 1991.

[23] C. Diedrich, "Großammoniten-Kolke, Bioturbation und Fische im Cenoman/Turon-Grenzbereich von NW-Deutschland," Terra Nostra, vol. 1, pp. 1-24, 2001.

[24] R. Appfel, Multi-Stratigraphie und Faziesanalyse pelagischer Kalke aus der tiefen Oberkreide (Untercenoman-Unterconiac) im Straßeneinschnitt am Ostwestfalen Damm (B61) östlich des Teutoburger Waldes und südlich von Bielefeld (NRW) [Diploma thesis], University of Berlin, 1993.

[25] R. G. Bromley and A. A. Ekdale, "Chondrites: a trace fossil indicator of anoxia in sediments," Science, vol. 224, no. 4648, pp. 872-874, 1984.

[26] C. Diedrich and U. Scheer, "Vertebrates from coastal carbonate sands of the Upper Santonian as tool for the southern ProtoNorth Sea Basin intertidal dinosaur exchange bridge reconstructions in Europe," Central European Journal of Geosciences, 2014 , in review.

[27] C. Diedrich, "Die Großammoniten-Kolktaphozönosen des Puzosia-Event I (Ober-Cenoman) von Halle/Westf. (NWDeutschland)," Münstersche Forschungen zur Geologie und Paläontologie, vol. 90, pp. 1-208, 2001.

[28] R. Eastman, "Beiträge zur Kenntnis der Gattung Oxyrhina mit besonderer Berücksichtigung von Oxyrhina mantelli Ag," Palaeontographica, vol. 41, pp. 149-192, 1895.

[29] K. Shimada, "Ontogenetic parameters and life history strategies of the Late Cretaceous lamniform shark, Cretoxyrhina mantelli, based on vertebral growth increments," Journal of Vertebrate Paleontology, vol. 28, no. 1, pp. 21-33, 2008.

[30] G. D’Erasmo, “Catalogo dei pesci fossili delle Tre Venezie," Regia Universitá di Padova, Memoria dell'Instituto Geologico, vol. 6, pp. 1-188, 1922.

[31] A. S. Woodward, Catalogue of the Fossil Fishes in the British Museum (Natural History). Part I, Elasmobranchii, London, UK, 1889.

[32] A. S. Woodward, "Notes on the sharks' teeth from British Cretaceous formations," Proceedings of the Geological Association, vol. 13, pp. 190-200, 1894.

[33] F. Dixon, The Geology and Fossils of the Tertiary and Cretaceous Formations of Sussex, Longman Brown Green and Longmans, London, UK, 1850.

[34] A. E. Longbottom and C. Patterson, "Fishes," Palaeontological Association of London Field Guides to Fossils, vol. 2, pp. 238-265, 1987.

[35] G. A. Mantell, The Fossils of the South Downs, or Illustrations of the Geology of Sussex, Thomas Davison, London, UK, 1822.

[36] G. A. Mantell, Wonders of Geology, London, UK, 1839.
[37] A. S. Woodward, “The fossil fishes of the English chalk-part 4," Monographs of the Paleontological Society, vol. 1908, pp. 129-152, 1908.

[38] S. Applegate, "The vertebrate fauna of the Selma Formation of Alabama VIII the fishes," Fieldiana Geology Memoires, vol. 3, pp. 383-433, 1970.

[39] J. Bourdon and M. J. Everhart, "Analysis of an associated Cretoxyrhina mantelli dentition from the Late Cretaceous (Smoky Hill Chalk, Late Coniacian) of western Kansas," Transactions of the Kansas Academy of Science, vol. 114, no. 1-2, pp. 15-32, 2011.

[40] V. Kipprijanoff, "Fischreste im Kurskischen eisenhaltigen Sandsteine," Bulletin de la Societé Imperiale des Naturalistes de Moscou, vol. 33, pp. 1-70, 1860.

[41] C. Hasse, "Einige seltene palaeontologische Funde," Palaeontographica N.F., vol. 31, pp. 3-10, 1885.

[42] A. E. Reuss, Die Versteinerungen der Böhmischen Kreideformation, Zweite Abtheilung (1846), Schweizbart' sche Verlagsbuchhandlung, Erste Abtheilung, Stuttgart, Germany, 1845.

[43] H. B. Geinitz, Grundriss der Versteinerungskunde, Arnoldische Buchhandlung, Dresden, Germany.

[44] H. B. Geinitz, "Das Elbthalgebirge in Sachsen. Erster Theil. Der Untere Quader," Palaeontographica, vol. 20, pp. 1-319, 1875.

[45] H. B. Geinitz, "Das Elbthalgebirge in Sachsen. Zweiter Theil. Der Mittlere und Obere Quader," Palaeontographica, vol. 20, pp. 1-245, 1875.

[46] A. Fritsch, Die Reptilien und Fische der Böhmischen Kreideformation, Verlag des Verfassers in Comisssion bei Fr. Rivnác, Prag, Czech Republic, 1878.

[47] A. Fritsch, "Studien im Gebiete der böhmischen Kreideformation. Ergänzung zu Band I. Illustriertes Verzeichnis der Petrefacten der cenomanen Korycaner Schichten," Archiv der Naturwissenschaftlichen Landesdurchforschung von Böhmen, vol. 15, pp. 1-101, 1911.

[48] C. E. Fischer, "Die Fischreste aus den Plaener Schichten von Plauen, Strehlen, Weinböhla und Gromedlitz," Allgemeine Deutsche Naturwissenschaftliche Zeitung, vol. 2, pp. 134-145, 1856.

[49] F. Roemer, Geologie von Oberschlesien, Druck von Robert Nischkowski, Breslau, Germany, 1870.

[50] J. Leidy, "Contributions to the extinct vertebrate fauna of the Western Territories," Reports of the U.S. Geological Survey, vol. 1, pp. 1-358, 1873.

[51] S. W. Williston, "Cretaceous fishes. Selachians and Pycnodonts," University Geological Survey of Kansas, vol. 6, pp. 237-256, 1900.

[52] J. B. Witzke, "Cretaceous vertebrate fossils of Iowa and nearby areas of Nebraska, South Dakota, and Minnesota," in Iowa Geolgical Survey, Guidebook To Cretaceous Stratigraphy and Sedimentation in Northwest Iowa, Northeast Nebraska and Southeast South Dakota, vol. 105, p. 122, 1981.

[53] M. Lériche, "Les poissons du Crétacé et du Nummulitique de l' Aude," Bulletin de la Societé Géologique Français V, vol. 6, pp. 375-402, 1936.

[54] E. Stromer and W. Weiler, "Beschreibung von Wirbeltieren aus dem nubischen Sandstein Oberägyptens und aus ägyptischen Phosphaten, nebst Bemerkungen über die Geologie der Umgegend von Mahamed in Oberägypten," Abhandlungen der Bayrischen Akademie der Wissenschaften N.F., vol. 7, pp. 1-42, 1930.

[55] M. Lériche, "Revision de la faune ichthyologique des terrains Crétacés du nord de la France," Annales de la Societé Geologique du Nord, vol. 31, pp. 87-154, 1902. 
[56] W. Jordan, "Fischreste aus der oberen Kreide des paderborner Landes," Natur und Heimat, vol. 7, pp. 4-6, 1940.

[57] D. L. Wolberg, "Selachians from the late Cretaceous (Turonian) Atarque Sandstone Member of the Tres Hermanos Formation, Sevilleta Grant, Socorro County, New Mexico," New Mexico Geology, vol. 7, pp. 1-7, 1985.

[58] D. L. Wolberg, "Selachians from the Atarque Sandstone Member of the Tres Hermanos Formation (Upper Cretaceous: Turonian), Sevilleta Grant near La Joya, Socorro County, New Mexico," New Mexico Mineralogy and Mineral Resources Circular, vol. 195, pp. 7-19, 1985.

[59] C. Werner, "Biostratigraphical results of investigations on the Cenomanian elasmobranchian fauna of Bahariya Oasis, Egypt," Berliner Geowissenschaftliche Abhandlungen, Reihe A, vol. 120, no. 2, pp. 943-956, 1990.

[60] T. E. Williamson, J. I. Kirkland, and S. G. Lucas, "Selachians from the Greenhorn cyclothem ("middle" Cretaceous: Cenomanian-Turonian), Black Mesa, Arizona, and the paleogeographic distribution of late Cretaceous selachians," Journal of Paleontology, vol. 67, no. 3, pp. 447-474, 1993.

[61] H. E. Sauvage, "Catalogue des pissons des formations secondaires du Boulonnais," Mémoires de la Societé Akademie Boulongne-Sur Mer, vol. 2, pp. 53-147, 1867.

[62] H. E. Sauvage, "Recherches sur les poissons fossiles des terrains Crétacé de la Sarthe," Bibliothèque de L'École des Hautes Études, Section des Sciences Naturelles, vol. 5, pp. 1-43, 1872.

[63] H. Scupin, "Die Löwenberger Kreide und Ihre Fauna," Palaeontographica, vol. 6, pp. 1-275, 1913.

[64] H. Cappetta, "Selachiens from the Carlile Shale (Turonian) of South Dakota," Journal of Paleontology, vol. 47, pp. 504-514, 1973.

[65] G. R. Case, T. T. Tokaryk, and D. Baird, "Selachians from the Niobrara Formation of the Upper Cretaceous (Coniacian) at Carrot River, Saskatchewan, Canada," Canadian Journal of Earth Sciences, vol. 27, no. 8, pp. 1084-1094, 1990.

[66] M. Siverson and J. Lindgren, "Late Cretaceous sharks Cretoxyrhina and Cardabiodon from Montana, USA," Acta Palaeontologica Polonica, vol. 50, no. 2, pp. 301-314, 2005.

[67] R. Marcinowski and A. Radwanski, "The Mid-Cretaceous transgression onto the Central Polish Uplands (marginal part of the Central European Basin)," Zitteliana, vol. 10, pp. 65-95, 1983.

[68] S. L. Cumbaa, C. Schröder-Adams, R. G. Day, and A. J. Phillips, "Cenomanian bonebed faunas from the northeastern margin, Western Interior Seaway, Canada," Bulletin of New Mexico Museum of Natural History and Science, vol. 35, pp. 139-155, 2006.

[69] J. Hermann, "Contribution a la conaissance de la faune ichthyologique des phosphates du Maroc," Annales de la Societé Geologique Belgique, vol. 95, pp. 271-284, 1973.

[70] J. Hermann, "Die Selachier-Zähne aus der Maastricht-Stufe von Hemmoor, Niederelbe (NW-Deutschland)," Geologisches Jahrbuch A, vol. 61, pp. 129-159, 1982.

[71] T. Reinecke, H. Moths, A. Grant, and H. Breitkreutz, "Die Elasmobranchier des norddeutschen Chattiums, insbesondere des Sternberger Gesteins (Eochattium, Oberes Oligozän)," Palaeontos, vol. 8, pp. 1-135, 2005.

[72] M. Friedman, K. Shimada, M. J. Everhart et al., "Geographic and stratigraphic distribution of the Late Cretaceous suspensionfeeding bony fish Bonnerichthys gladius (Teleostei, Pachycormiformes)," Journal of Vertebrate Paleontology, vol. 33, pp. 35-47, 2013.
[73] N. Bardet, P. Wellnhofer, and D. Herm, "Discovery of ichthyosaur remains (Reptilia) in the Upper Cenomanian of Bavaria," Mitteilungen der Bayerischen Staatssamlung der historischen Geologie, vol. 34, pp. 213-220, 1994.

[74] C. Diedrich, "New ichthyosaur remains of Platypterygius cf. campylodon (Carter, 1846) (Ichthyopterygia, Reptilia) from the Cenomanian of NW Germany," Münstersche Forschungen zur Geologie und Paläontologie, vol. 93, pp. 97-108, 2002.

[75] M. J. Everhart, Oceans of Kansas-A Natural History of the Western Interior Sea, Indiana University Press, Bloomington, Ind, USA, 2005.

[76] D. A. Adams, "Trinacromerum bonneri, new species, last and fastest pliosaur of the Western Interior Seaway," Texas Journal of Science, vol. 49, no. 3, pp. 179-198, 1997.

[77] K. Carpenter, "A review of short-necked plesiosaurs from the Cretaceous of the Western Interior, North America," Neues Jahrbuch fur Geologie und Palaontologie Abhandlungen, vol. 201, no. 2, pp. 259-287, 1996.

[78] B. A. Schumacher and J. E. Martin, "Polycotylus sp.: a shortnecked plesiosaur from the Niobrara Formation (Upper Cretaceous) of South Dakota," Journal of Vertebrate Paleontology, vol. 15, no. 3, p. 52A, 1995.

[79] C. U. Schloenbach, "Polyptychodon owen vom Dniestr-Ufer bei Onuth in der Bukowina," Jahrbuch der Geologischen Reichsanstalt Wien, vol. 18, pp. 462-465, 1868.

[80] H. G. Seeley, "On an associated series of cervical and dorsal vertebrae of Polyptychodon, from the Cambridge Upper Greensand, in the Woodwardian Museum of the University of Cambridge," Quarterly Journal of the Geological Society of London, vol. 32, pp. 433-436, 1876.

[81] H.-É. Sauvage, "De la présence du genre Polyptychodon dans les sables verts de la Meuse," Bulletin de la Societè Histoire Naturelle Autun, vol. 16, pp. 321-323, 1903.

[82] S. P. Welles and B. H. Slaugther, "The first record of the plesiosauria genus Polyptychodon (Pliosauridae ) from the New World," Journal of Paleontology, vol. 37, pp. 131-133, 1963.

[83] S. P. Welles, "Elasmosaurid plesiosaurs with a description of the new material from California and Colorado," University of California Memoirs, vol. 13, pp. 125-254, 1943.

[84] M. J. Everhart, "Evidence of feeding on mosasaurs by the late Cretaceous lamniform shark, Cretoxyrhina mantelli," Journal of Vertebrate Paleontology, vol. 17, pp. 43A-44A, 1999.

[85] M. J. Everhart, P. A. Everhart, and K. Shimada, "A new specimen of shark bitten mosasaur vertebrae from the Smoky Hill Chalk (Upper Cretaceous) in western Kansas," Kansas Academy of Science Pittsburg, vol. 14, p. 19, 1995.

[86] M. J. Polcyn, G. L. Jr. Bell, K. Shimada, and M. J. Everhart, “The oldest North American mosasaurs (Squamata: Mosasauridae) from the Turonian (Upper Cretaceous) of Kansas and Texas with comments on the radiation of major mosasaur clades," in Proceedings of the 2nd Mosasaur Meeting, Fort Hays Studies Special Issue 3, pp. 137-155, Fort Hays State University, Hays, Kan, USA, 2008.

[87] M. J. Everhart, "Rapid evolution, diversification and distribution of mosasaurs (Reptilia; Squamata) prior to the K-T Boundary," in Proceedings of the 11th Annual Symposium in Paleontology and Geology, pp. 16-27, Casper, Wyo, USA, 2005. 

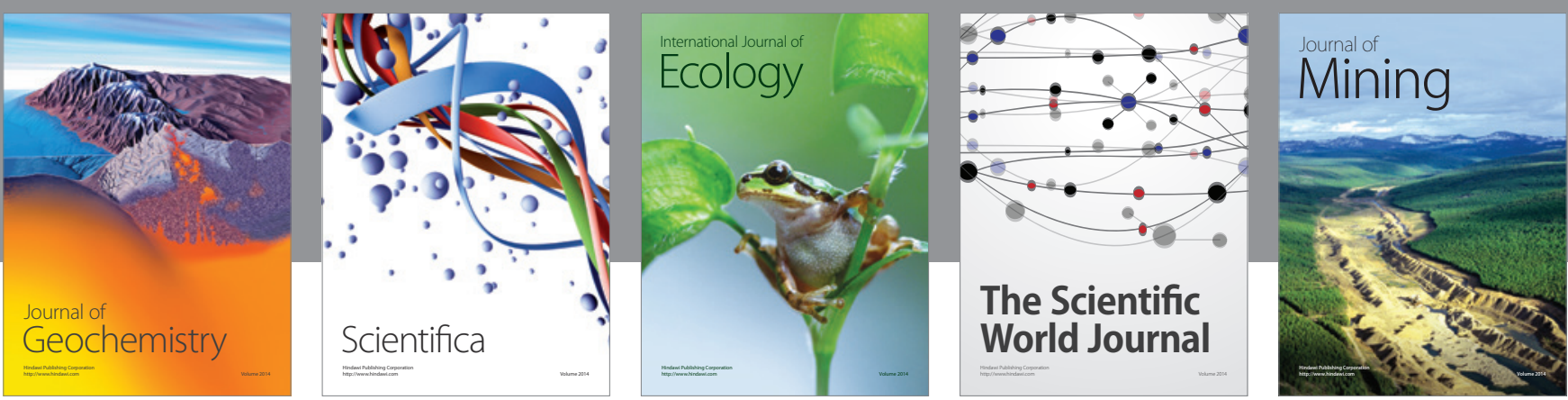

The Scientific World Journal
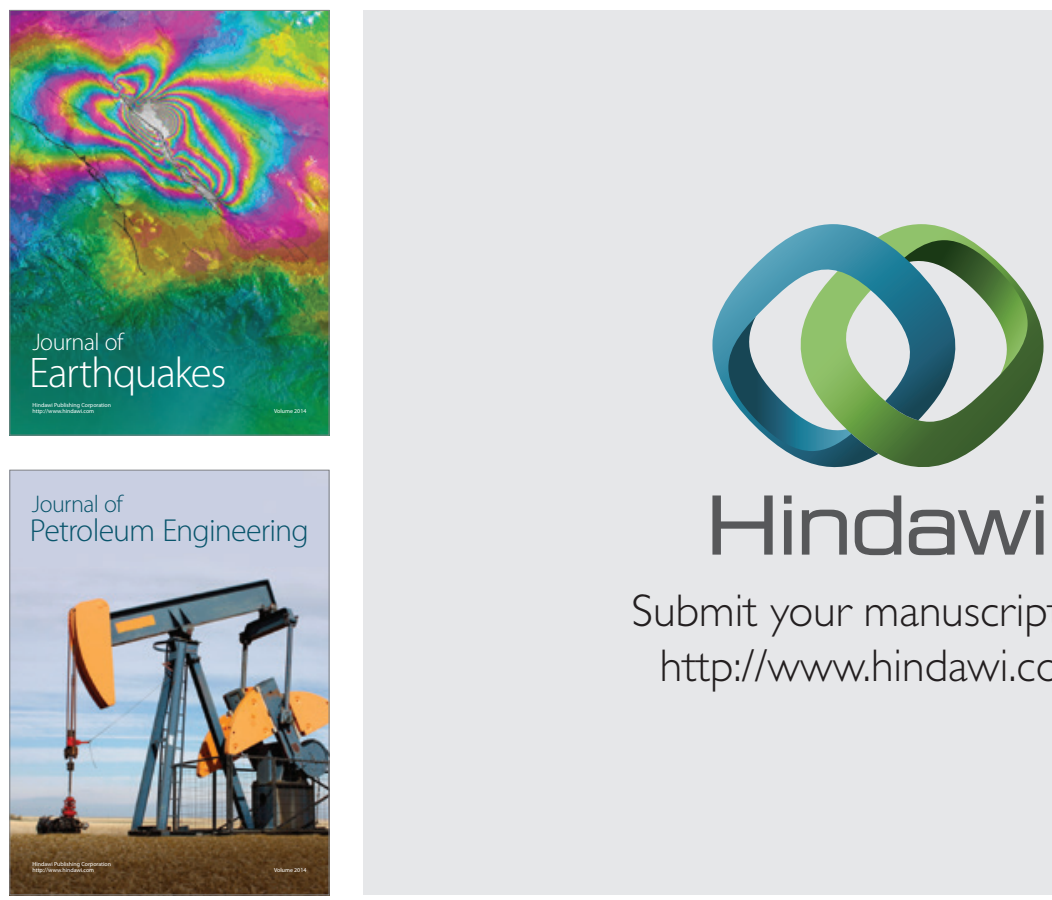

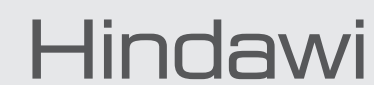

Submit your manuscripts at

http://www.hindawi.com
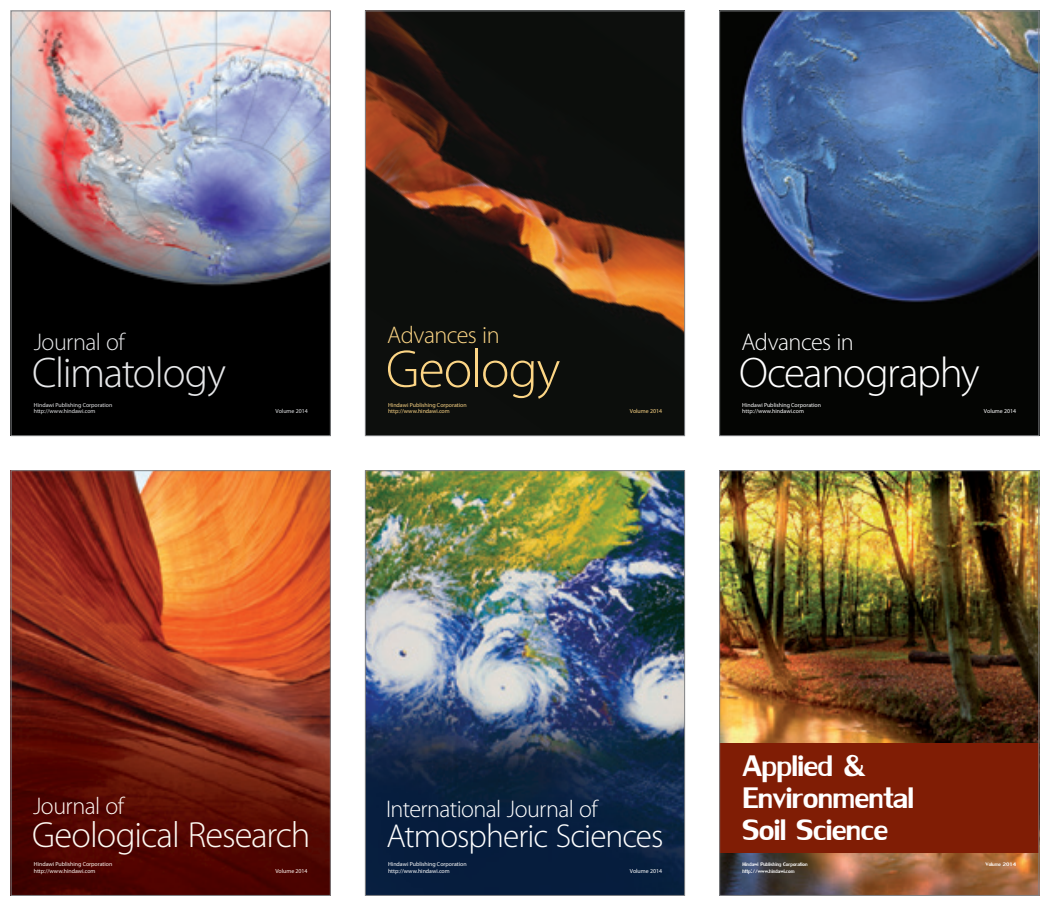
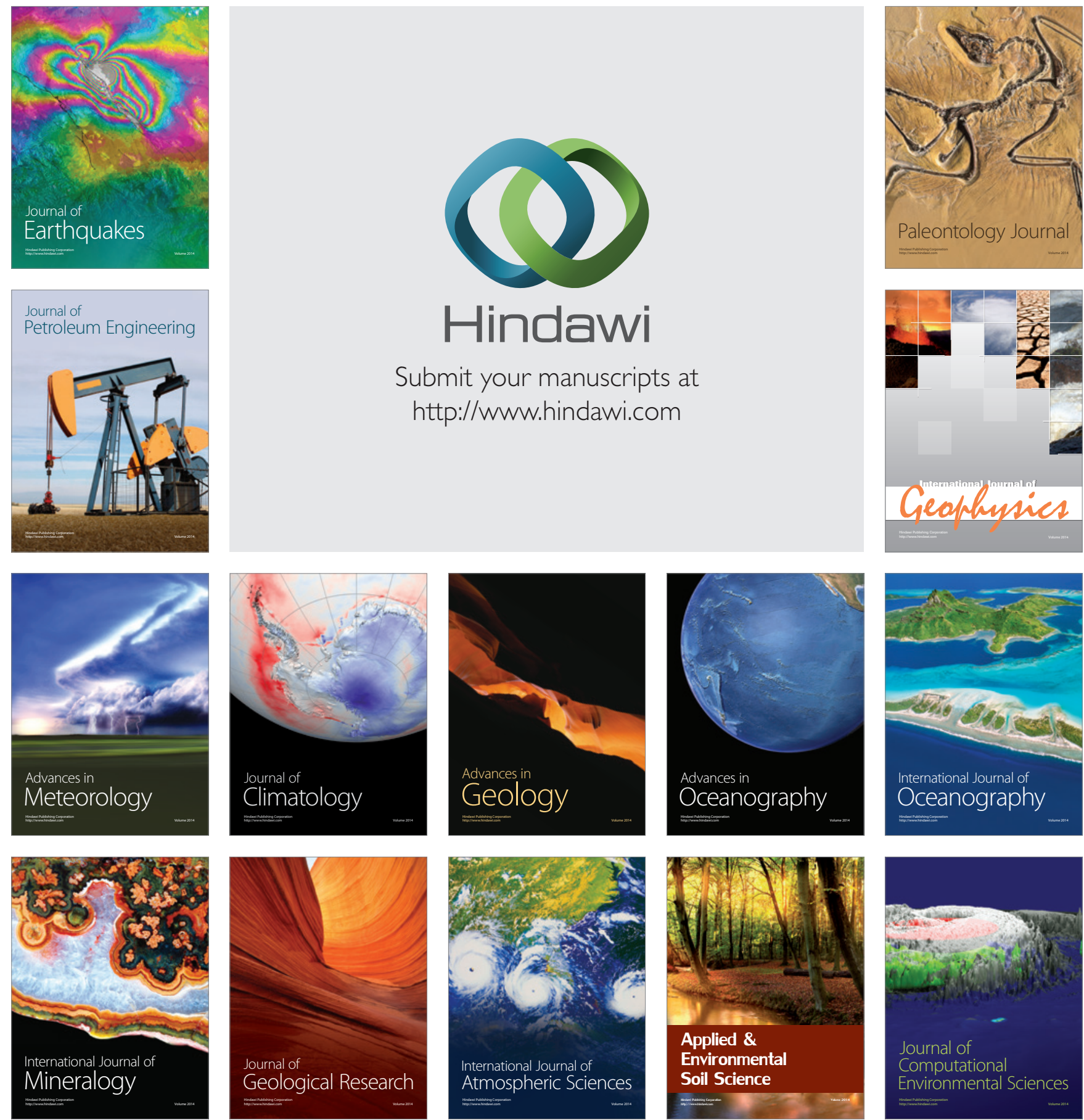